\title{
Democratic Republic of Timor-Leste: 2008 Article IV Consultation-Staff Report; Staff Statement; Public Information Notice on the Executive Board Discussion; and Statement by the Executive Director for the Democratic Republic of Timor-Leste
}

Under Article IV of the IMF's Articles of Agreement, the IMF holds bilateral discussions with members, usually every year. In the context of the 2008 Article IV consultation with the Democratic Republic of Timor-Leste, the following documents have been released and are included in this package:

- $\quad$ The staff report for the 2008 Article IV consultation, prepared by a staff team of the IMF, following discussions that ended on April 30, 2008, with the officials of the Democratic Republic of Timor-Leste on economic developments and policies. Based on information available at the time of these discussions, the staff report was completed on June 10, 2008. The views expressed in the staff report are those of the staff team and do not necessarily reflect the views of the Executive Board of the IMF.

- A staff statement of June 25, 2008 updating information on recent developments.

- $\quad$ A Public Information Notice (PIN) summarizing the views of the Executive Board as expressed during its June 25, 2008 discussion of the staff report that concluded the Article IV consultation.

- $\quad$ A statement by the Executive Director for the Democratic Republic of Timor-Leste.

The document listed below has been or will be separately released.

Selected Issues Paper and Statistical Appendix

The policy of publication of staff reports and other documents allows for the deletion of market-sensitive information.

\author{
Copies of this report are available to the public from \\ International Monetary Fund • Publication Services \\ $70019^{\text {th }}$ Street, N.W. • Washington, D.C. 20431 \\ Telephone: (202) 623-7430 • Telefax: (202) 623-7201 \\ E-mail: publications@imf.org Internet: http://www.imf.org
}

Price: $\$ 18.00$ a copy

\section{International Monetary Fund Washington, D.C.}



INTERNATIONAL MONETARY FUND

\author{
DEMOCRATIC REPUBLIC OF TIMOR-LESTE
}

\title{
Staff Report for the 2008 Article IV Consultation
}

Prepared by the Staff Representatives for the 2008 Consultation with Timor-Leste

Approved by Kalpana Kochhar and Mark Plant

June 10,2008

- $\quad$ Article IV discussions took place in Dili during April 16-30. Discussions were held with President Ramos-Horta, Prime Minister Gusmão, Finance Minister Pires, General Manager of the Banking and Payments Authority Vasconselos, other senior officials, and representatives of donors, the business community, and civil society.

- In addition to Ms. Creane (head), the staff team included Mr. Thomas (APD), Ms. Takahashi (FAD), and Mr. Rasmussen (Resident Representative). Mr. Cardoso (OED) also joined the discussions. The team coordinated with the World Bank and Asian Development Bank.

- $\quad$ The last Article IV consultation was concluded on January 29, 2007. Directors' comments may be found at http://www.imf.org/external/np/sec/pn/2007/pn0724.htm

- Timor-Leste uses the U.S. dollar as its official currency. It has accepted the obligations of Article VIII, Sections 2, 3, and 4, and maintains an exchange system free of restrictions on payments and transfers for current international transactions.

- Data provision to the Fund is deficient as weaknesses, especially in the national accounts and the balance of payments, hinder analysis (Annex IV).

- The authorities indicated their intention to publish the staff report and background documents. A press statement was issued by the Resident Representative office at the end of the consultation. 


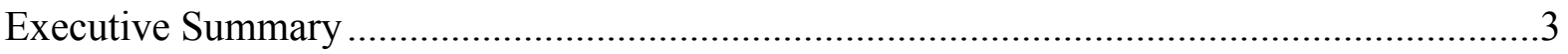

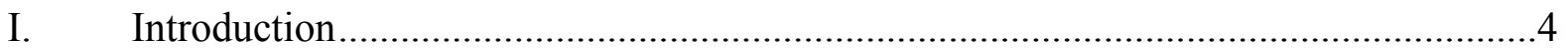

II. The Economic Setting ........................................................................................

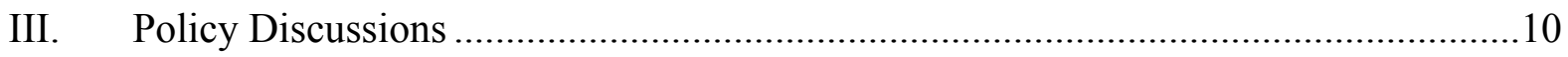

A. How to Accelerate Growth and Reduce Poverty? ................................................11

B. How Much Should the Government Spend to Promote Growth Without Risking

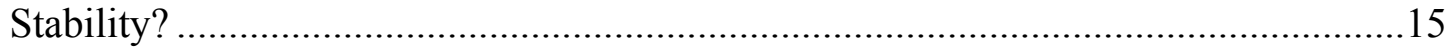

C. Is the Current Exchange Rate Regime and Level Appropriate? .............................17

D. How Best to Promote Financial Intermediation? ................................................. 18

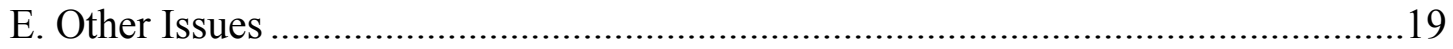

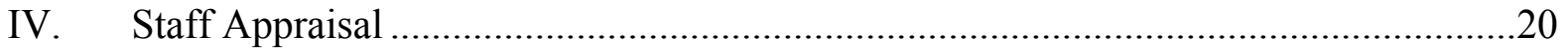

\section{Boxes}

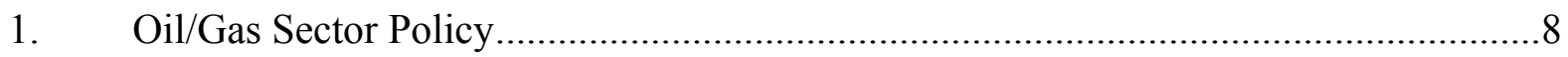

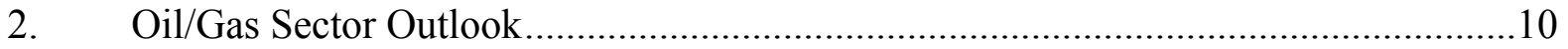

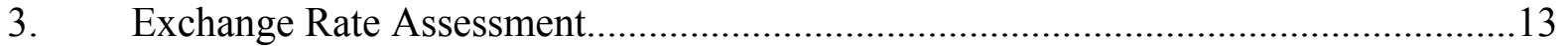

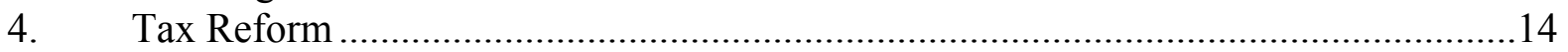

Figures

1. Regional and Global Comparisons ...............................................................22

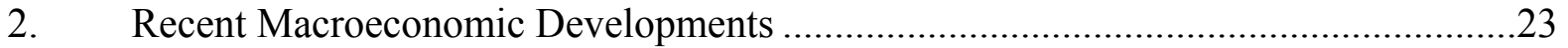

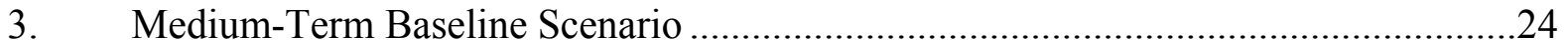

Tables

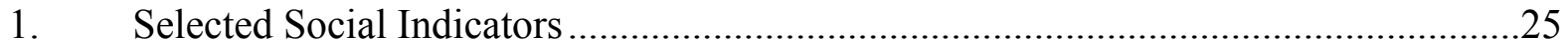

2. Selected Economic Indicators, 2003-08 ...............................................................26

3. Central Government Budget, FY2004/05-2008 …................................................27

4. SIPs Combined Sources Budget, FY2004/05-2008 …............................................28

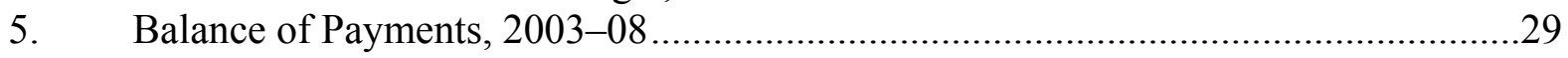

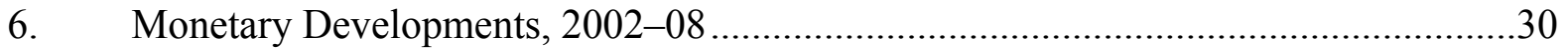

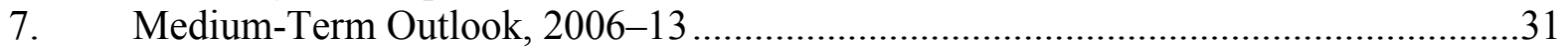

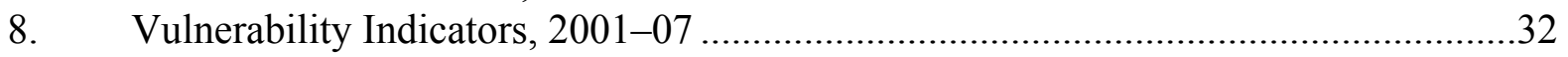




\section{EXECUTIVE SUMMARY}

\section{Economic Setting}

- $\quad$ The civil unrest of the past two years interrupted Timor-Leste's initial efforts to develop a stable and healthy economy. The security and political situation remains fragile.

- $\quad$ Despite the domestic violence, growth rebounded in 2007, buoyed by higher public spending. Inflation has risen sharply, but remains low relative to comparators. The off-shore oil/gas sector has not been affected by the domestic crisis, and receipts increased to more than triple the size of non-oil GDP in 2007.

- $\quad$ The country remains among the least developed globally, and its outlook is constrained by the security situation, poor budget execution (especially investment spending), and a weak investment environment.

\section{Key Policy Issues}

- $\quad$ The key challenge remains how to use growing oil/gas revenue to develop a sustainable non-oil economy, while alleviating near-term social problems and maintaining macroeconomic stability.

- $\quad$ Stepped up public and private investment is needed, especially in infrastructure and human capital. Fast-tracked updating of the national development plan is essential, along with expedited structural reforms to spur private activity.

- $\quad$ The authorities' long-term fiscal sustainability strategy targeting inter-generational equity through use of a petroleum fund, including identification of annual sustainable spending limits, should be maintained. There is ample room under the fund's arrangements for needed spending to address social and development needs.

- $\quad$ Steps to improve budget execution to enable targeted fiscal spending to rise to sustainable levels are encouraged, keeping in mind administrative and absorptive capacity constraints that could lead to inflation pressure and poor quality spending.

- $\quad$ The authorities reaffirmed their commitment to use of the U.S. dollar as the official currency, given its success in helping keep inflation in check and the lack of capacity to manage monetary and exchange rate policy.

- $\quad$ The government should focus on creating a supportive environment for a stable financial system based on sound business practices to encourage financial deepening. 


\section{INTRODUCTION}

1. Timor-Leste's initial efforts to develop a stable and healthy economy were interrupted by the civil unrest of the past two years. Following independence in 2002, the early adoption of prudent fiscal and monetary policies contributed to low inflation and accelerating economic growth, while the onset of oil/gas revenue inflows brightened the economic outlook. However, the domestic violence that first erupted in April 2006 brought about economic contraction and diminished prospects. ${ }^{1}$ Although the economy has now partially rebounded, non-oil GDP per capita remains below 2002 levels and the country is the least developed in the region. Progress toward the country's development objectives, including the Millennium Development Goals, has been limited. ${ }^{2}$ That said, Timor-Leste's large petroleum wealth, if effectively harnessed, still offers the potential for a prosperous future.

2. The security situation remains fragile and an economic burden. The past two years have seen persisting political tensions, several changes of government, and outbreaks of violence between regional communities. Rebel attacks on the President and Prime Minister in February dealt a fresh blow to the struggling nation. The President survived lifethreatening bullet wounds, rebels have surrendered, and disturbances have since diminished. Still, upwards of 10 percent of the population remains internally displaced and widespread poverty remains a source of instability. The continuing civil unrest has damaged investor confidence, while the population's still large development needs amidst growing petroleum fund savings have put the authorities under considerable pressure to show results.

\section{The key challenge remains how to manage the abundant petroleum revenue to} alleviate near-term social problems and develop a sustainable non-oil economy. The existing National Development Plan (NDP) focuses on steps to promote growth, including a long-term oil-and-gas revenue saving policy supported by a petroleum fund; well-targeted development spending under sector-investment programs; a monetary and exchange rate regime that preserves macroeconomic stability; and a private-investment-friendly environment. The government elected in mid-2007 has launched a discussion of national priorities defining near-term goals for recovery, and plans to update the NDP later this year. The current direction is toward greater emphasis on addressing short-term needs. Still limited institutional capacity and a difficult starting point remain key constraints to progress.

\footnotetext{
${ }^{1}$ A UN mission (UNMIT) was established in mid-2006 with a large contingent of police. An Australian-led International Stabilization Force provides additional troops.

${ }^{2}$ Timor-Leste ranks 150 out of 177 in the UN's 2007/2008 Human Development Report.
} 


\section{The Economic Setting}

\section{Current Macroeconomic Conditions}

4. Growth rebounded in 2007, although the civil unrest continues to undermine the economy. ${ }^{3}$ Following negative growth in 2006, the peak year for the civil unrest, non-oil growth is estimated to have reached almost 8 percent in 2007 and should remain high in 2008. Growth is driven mainly by the public sector, as government expenditure surges and donor spending remains high. Agricultural production contracted in 2007 due to drought and locust infestations. Output of coffee, the main non-oil export commodity, fell by an estimated 20 percent. Private sector activity remains subdued by the security situation.

\section{Inflation has risen sharply, but} remains low relative to regional comparators. Consumer prices increased by 8.9 percent in 2007 and are likely to stay high in 2008, driven by rising global food prices and reflecting food's 60 percent weight in the CPI basket. Fuel prices have also risen in line with international prices. While government subsidies for rice have partially shielded consumers, the threat of rice shortages looms. Excluding food prices, inflation was relatively low, although signs of increased demand-side price pressures are emerging in tight markets, e.g., in construction materials.

\section{The weakening U.S. dollar and low} inflation contributed to a moderate depreciation of the real effective exchange rate over the past year. On a nominal trade-weighted basis, the exchange rate is unchanged relative to 2004.
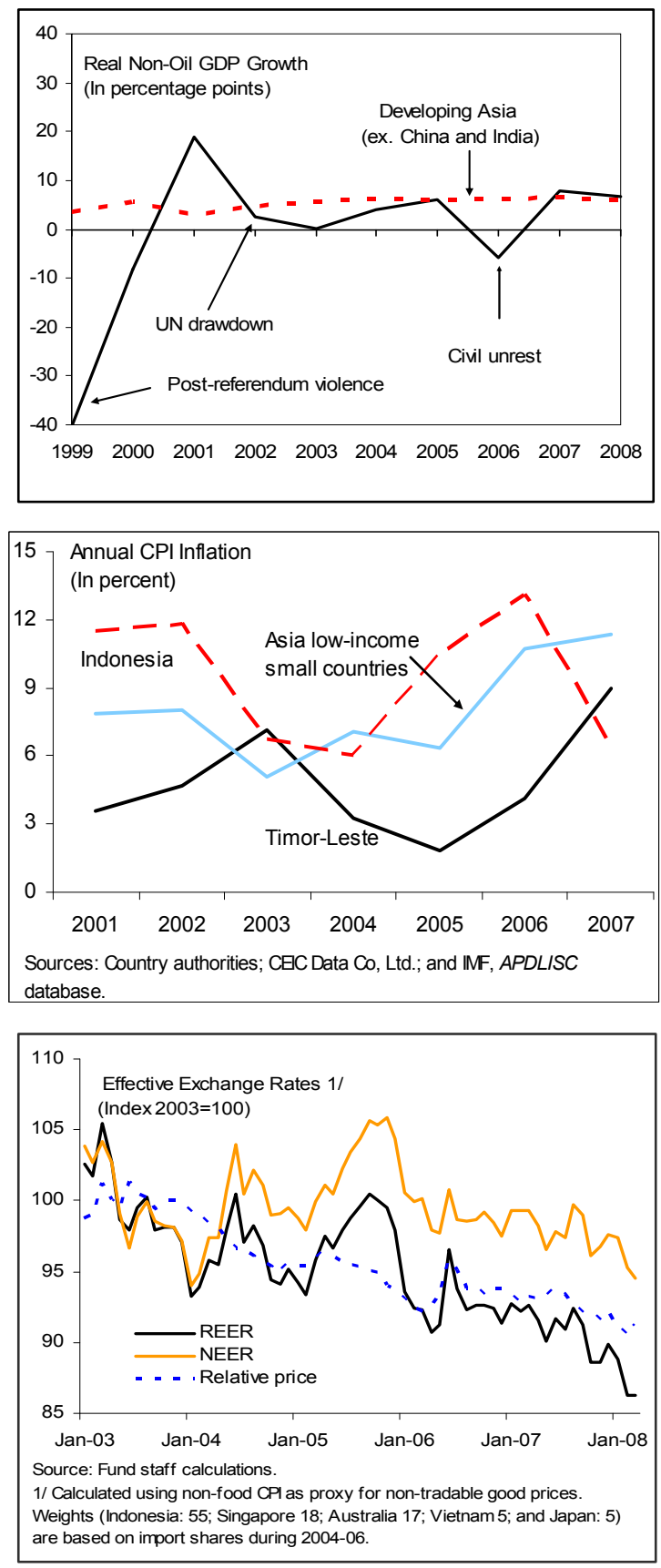

\footnotetext{
${ }^{3}$ National accounts and balance of payments estimates and projections are prepared with staff assistance on the basis of limited information.
} 


\section{Revenue from off-shore oil/gas continues to surge, reflecting high international} prices. Petroleum revenue reached 340 percent of non-oil GDP in 2007, with petroleum fund assets increasing to \$2.6 billion at end-March 2008 (about 6 times non-oil GDP).
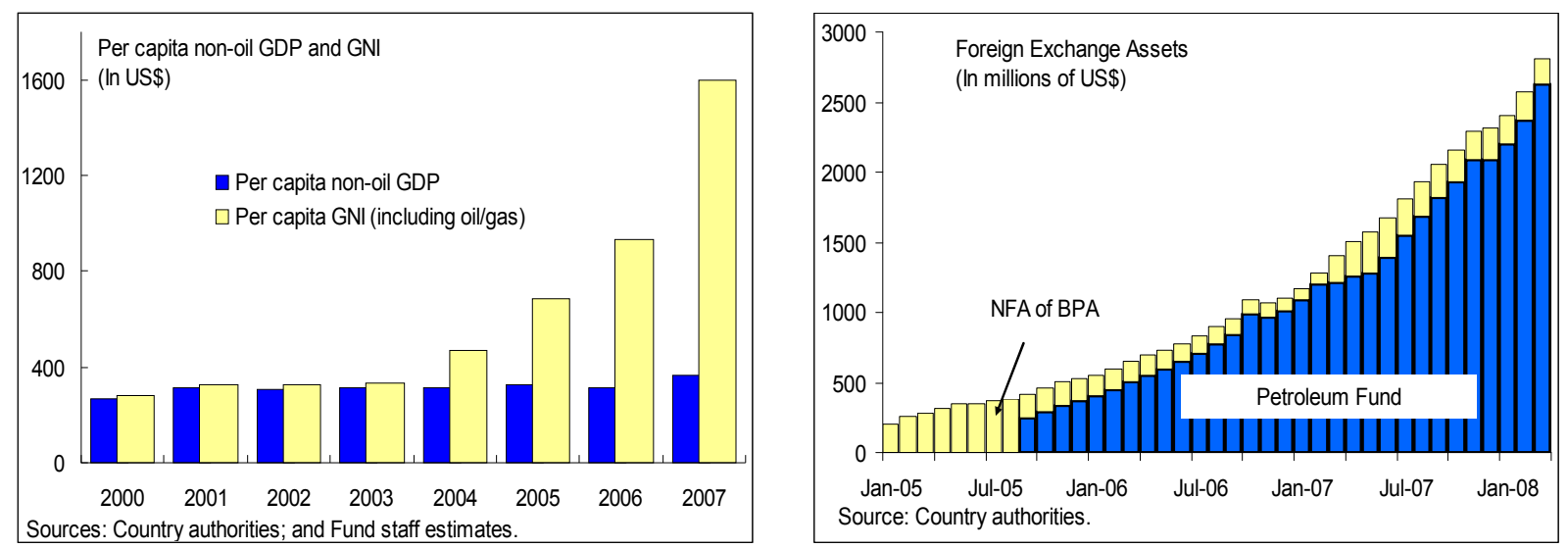

8. The large revenue inflows more than offset a steep increase in government expenditure, as external and fiscal surpluses further widened. Central government spending almost doubled in FY2006/07, with a further increase in spending during the second half of 2007, as reflected in expanding non-oil deficits. ${ }^{4}$ Government expenditure drove a surge in merchandise imports, which also almost doubled to an estimated 51 percent of non-oil GDP.

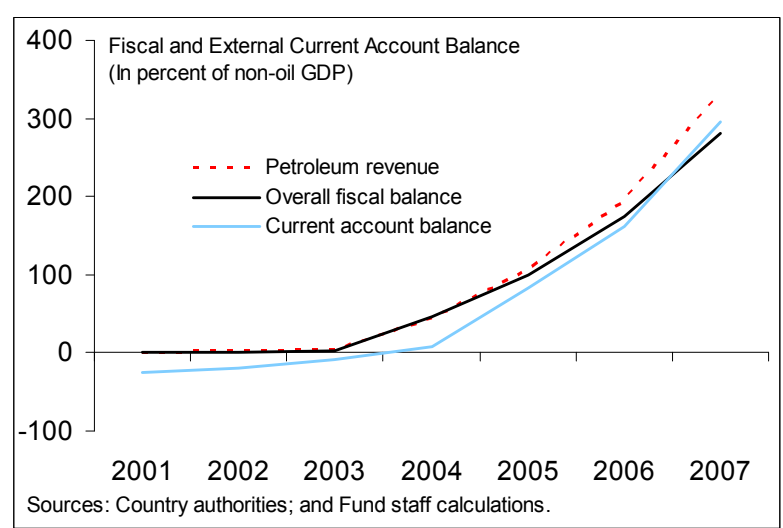

9. The increase in government expenditure has more than offset a gradual decline in donor spending. On a "combined sources" basis, which includes donor spending for projects identified in the national development plan, total public sector expenditure in FY2008 is expected to reach 101 percent of non-oil GDP. Although the recent civil unrestrelated humanitarian needs have led to new commitments, international assistance is expected to decline further over the coming years.

\footnotetext{
${ }^{4}$ The government budget moved to a calendar year basis in 2008; the second half of 2007 was covered by a transition budget.
} 


\begin{tabular}{|c|c|c|c|c|}
\hline \multicolumn{5}{|c|}{$\begin{array}{l}\text { Combined Sources Expenditure and Financing } \\
\text { (Cash spending in percent of non-oil GDP) }\end{array}$} \\
\hline & Average & & & \multirow{3}{*}{$\frac{2008}{\text { Proj. }}$} \\
\hline & 2000-05 & 2005/06 & 2006/07 & \\
\hline & \multicolumn{3}{|c|}{ Estimates } & \\
\hline Total expenditure & 68 & 64 & 83 & 101 \\
\hline Government 1/ & 21 & 27 & 50 & 73 \\
\hline Donors & 47 & 37 & 33 & 28 \\
\hline \multicolumn{5}{|l|}{ financed by: } \\
\hline Timor Leste revenue 2/ & 11 & 27 & 47 & 73 \\
\hline Budget support grants & 11 & 0 & 3 & 0 \\
\hline Off-budget donor financing & 47 & 37 & 33 & 28 \\
\hline \multicolumn{5}{|c|}{$\begin{array}{l}\text { Source: Timor-Leste authorities and staff estimates. } \\
1 / \text { Includes autonomous agencies. } \\
\text { 2/ Domestic revenue and petroleum fund transfers, net } \\
\text { of increase in government cash balances. }\end{array}$} \\
\hline
\end{tabular}

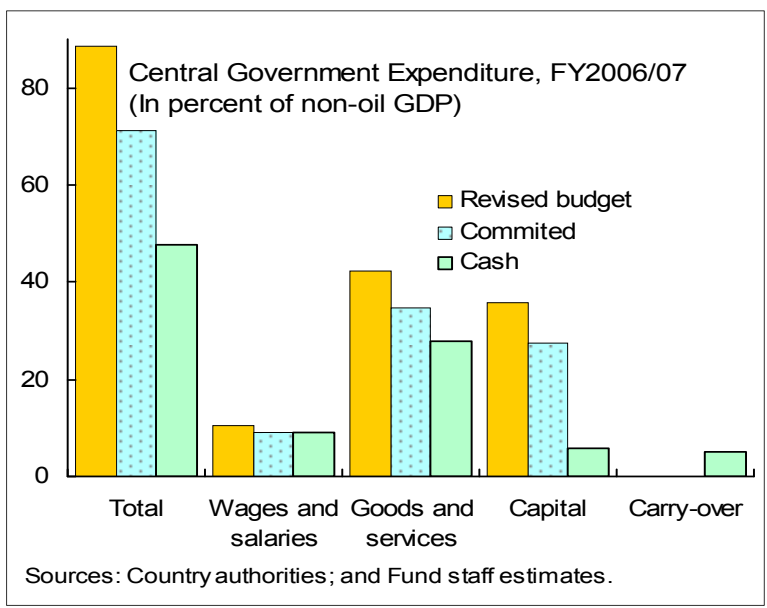

10. Notwithstanding the sharp increase, government spending to date remains far below budgeted levels, especially for investment spending. Budget execution remains constrained by weak planning and procurement capacity, as financial management reforms have not yet had a significant impact. In addition, a large stock of unspent commitments continues to be carried forward, despite efforts to tighten procedures.

\section{The planned 2008 mid-year budget update (MYBU) includes a significant} increase in current spending appropriations. Additional funds are being allocated for public works programs, transfers to refugees, veterans and the elderly, and higher public sector salaries. The MYBU also includes a large appropriation for rice purchases (5.8 percent of GDP) to be used for subsidized resale to local retailers, distribution to civil servants, and humanitarian assistance. The 2008 budget updated appropriations are expected to exceed the estimated "sustainable" spending level defined under the Petroleum Fund arrangement (Box 1), but actual cash expenditure is likely to be significantly lower.

\section{Access to financial services remains limited and credit growth has stalled.}

Notwithstanding the rapid expansion of credit to the private sector following independence (from a small base), still less than 2 percent of the population use banking facilities. A poor credit culture and weak enforcement of creditors' rights, compounded by the recent civil unrest, has led to an increase in nonperforming loans and provisioning to, respectively, 28 percent and 53 percent of bank lending at end-March 2008. While bank deposits have increased sharply, there has been little credit growth since 2006, with banks placing excess funds abroad.

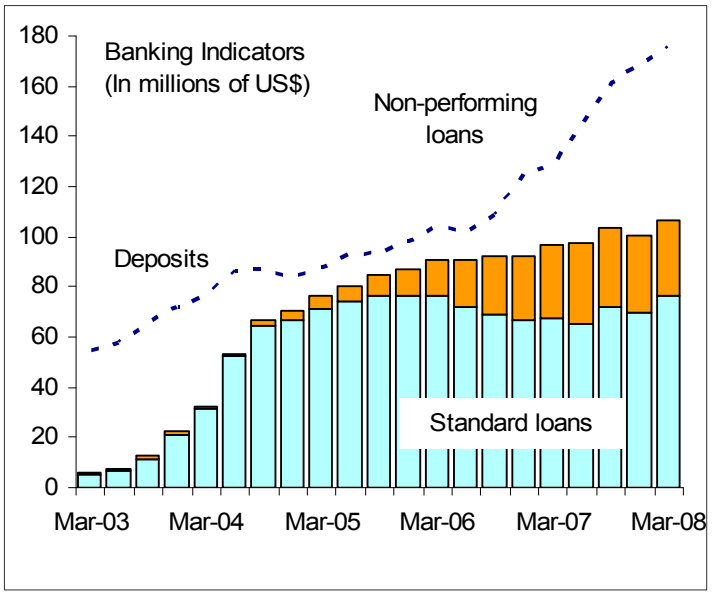




\section{Box 1. Oil/Gas Sector Policy}

- Under the Petroleum Fund Law, all oil/gas revenue is paid into the Petroleum Fund and transfers from the Fund to the budget are subject to a spending ceiling. The Fund is integrated into the central government budget with its resources only spent through the budget following Parliamentary approval.

- The "sustainable" spending ceiling is set to preserve the real value of the petroleum wealth for future generations and to reduce the impact of volatile oil/gas revenue. The annual "sustainable" spending ceiling is equal to the sum of domestic non-oil revenue and the estimated "sustainable" permanent interest income from the estimated long-term oil wealth (including oil/gas still in the ground). The Petroleum Fund Law (established with the assistance of an FAD resident expert), defines estimated sustainable income as 3 percent of total petroleum wealth (in contrast to Norway's more conservative approach of 4 percent of financial

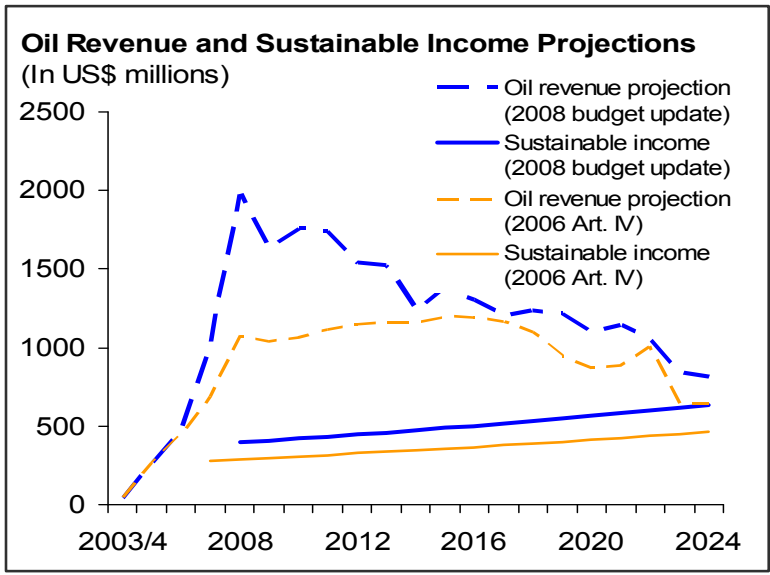
assets), with wealth estimated using prudent production (90 percent probability) and price (U.S. government's EIA low case scenario) projections, discounted using U.S. government securities' yields.

- All petroleum fund assets are invested abroad to minimize real exchange rate appreciation pressures and protect the primacy of the budget. An Investment Advisory Board recommends options for the investment strategy, which is currently implemented by the Banking and Payments Authority. Plans are underway to outsource part of the portfolio to the World Bank and BIS to gain experience before approaching commercial managers. Plans are also in hand to revise the Petroleum Fund Law to widen the allowable investment universe.

- Transparency. Quarterly detailed data are published, along with an Annual Report and the results of independent external audits of the monies received and the sustainable income estimates. An independent Consultative Council advises Parliament on Petroleum Fund issues. 
13. The civil unrest and mid-2007 general elections have delayed progress on structural reforms needed to support non-oil private sector activity. A raft of critical economic legislation is still pending. The court system is overwhelmed and there is no effective system to enforce contractual rights or settle disputes. Business licensing regulations appear to have become more complicated, rather than simplified as needed.

\section{Outlook and risks}

14. The medium-term outlook is for moderate non-oil growth. The outlook is shaped by, on the one hand, expected continued favorable oil/gas revenue prospects, and on the other, constraints on the government's capacity to spend. Given current trends, the "sustainable" spending level would be reached within a couple of years as budget execution gradually improves. Under that assumption, and based on continued slow reform of the business environment, the non-oil economy should grow by about 5 percent annually over the medium term. In this baseline scenario, government expenditure will continue to drive growth, with capital outlays increasing gradually to 20-25 percent of non-oil GDP, and

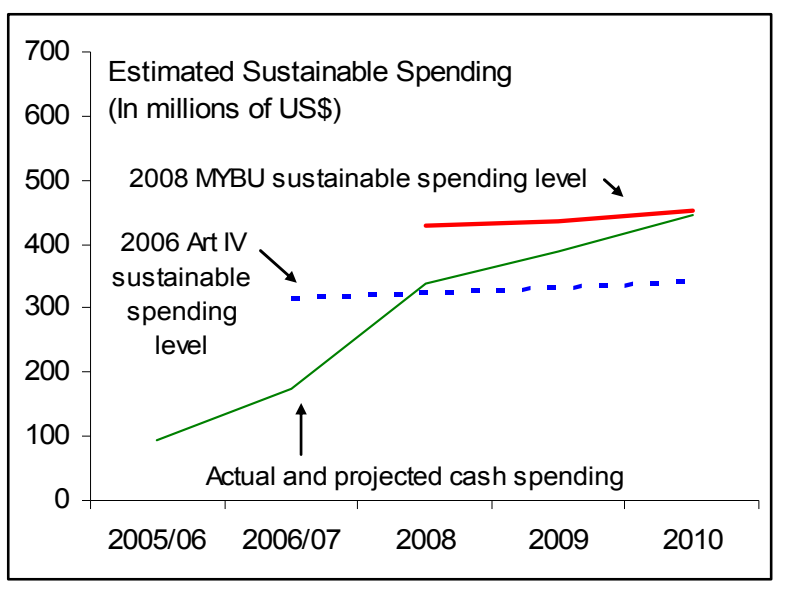
slowly declining inflation. Staff estimates that a more appropriate and forceful shift in the spending mix toward well-planned investment spending (bringing capital expenditure to about 30 percent of non-oil GDP) and successful business environment reform would be associated with annual growth rising to above 8 percent and less inflationary pressure than under the baseline scenario.

\section{Key risks include:}

- $\quad$ Projections of oil/gas revenue and sustainable income are highly sensitive to global oil market developments (Box 2). A disruption at Bayu-Undan, the one field currently in production, would also have a negative impact on government finances. On the upside, if realized, the Greater Sunrise project would almost double sustainable income.

- $\quad$ Continuing civil unrest and political uncertainty could distract from the pursuit of the reform agenda, increase the need for short-term humanitarian assistance, and deter private investment.

- $\quad$ Higher global food prices and regional market disruptions could lead to shortages and civil disturbances. 
- $\quad$ Failure to anchor government expenditure within a prioritized medium-term development plan in line with administrative capacity could lead to waste, governance risks, increased inflation, and little or no reduction in poverty.

- $\quad$ Rapid assumption of large-scale external borrowing, particularly in the absence of a prudent debt management strategy, could erode fiscal sustainability.

\section{Box 2. Oil/Gas Sector Outlook}

- Every \$20 change in global oil/gas prices changes estimated sustainable spending by $10-15$ percent of GDP annually.

- Pending agreement on a development plan, the Greater Sunrise oil/gas field (revenue potential of about $\$ 10$ billion or 10-15 times 2007 non-oil GDP) could commence production by 2015 , possibly doubling sustainable spending over the medium term.

- A recent commercial discovery identified a significant new field, and additional oil/gas fields offshore may be explored if oil/gas prices remain high.
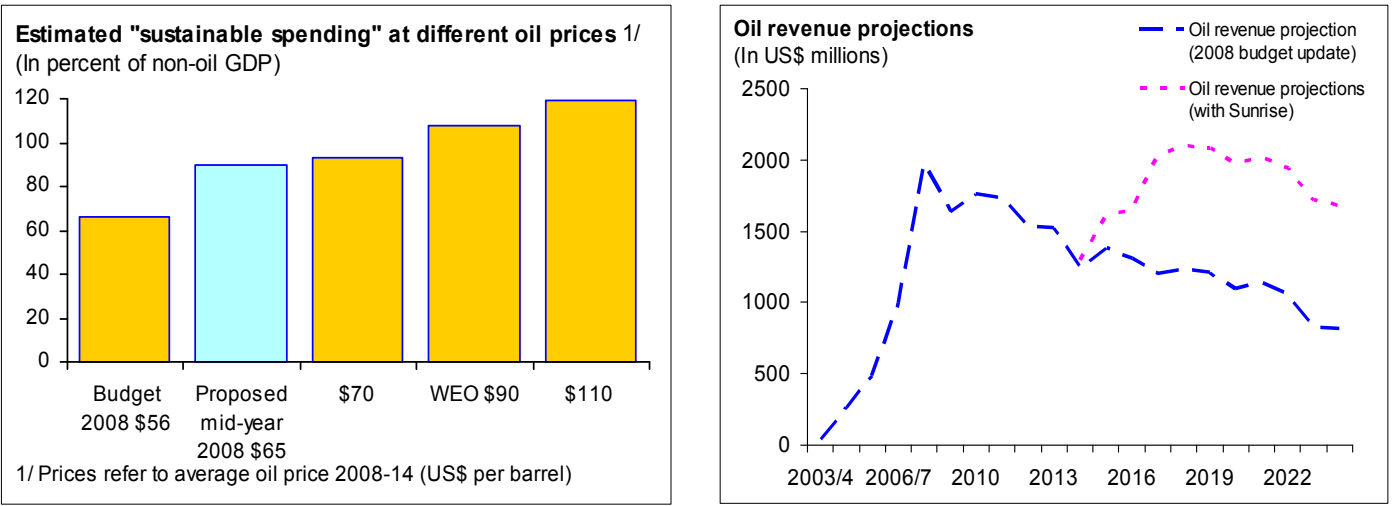

\section{Policy Discussions}

16. The discussions focused on the new government's plans for using the country's petroleum wealth to move onto a higher growth path, while addressing short-term social and security needs and maintaining macroeconomic stability. As the past year saw little progress on reforms due to the continuing domestic violence and midyear general elections, the fundamental objective remains the need to overcome weak institutions and infrastructure to better utilize available resources. At the same time, the civil unrest and threatening food insecurity have created pressing challenges in the short term. The discussions centered on four themes: 
- $\quad$ Building a strong and sustainable non-oil economy that would create employment and reduce poverty;

- $\quad$ Managing government spending to promote growth and address humanitarian needs without risking macroeconomic stability;

- $\quad$ Maintaining an appropriate exchange rate regime; and

- $\quad$ Promoting financial deepening to encourage growth.

\begin{tabular}{|c|c|}
\hline \multicolumn{2}{|c|}{ Authorities' Response to Recent Fund Policy Advice } \\
\hline Advice from the 2006 Article IV Discussions & Action Taken \\
\hline \multicolumn{2}{|c|}{$\begin{array}{ll}\text { Exchange Rate Policy } \\
\end{array}$} \\
\hline $\begin{array}{l}\text { Maintain current monetary and exchange regime } \\
\text { until institutional capacity is built. }\end{array}$ & $\begin{array}{l}\text { Continued commitment to current U.S. dollar } \\
\text { regime to allow build-up of institutional capacity. }\end{array}$ \\
\hline \multicolumn{2}{|c|}{ Fiscal Policy } \\
\hline $\begin{array}{l}\text { Maintain Petroleum Fund arrangements, including } \\
\text { saving policy. }\end{array}$ & Petroleum Fund strategy continued. \\
\hline $\begin{array}{l}\text { Improve budget execution to allow spending to } \\
\text { rise to sustainable levels. }\end{array}$ & $\begin{array}{l}\text { Budget execution strengthened, but further room } \\
\text { for improvement. }\end{array}$ \\
\hline $\begin{array}{l}\text { Introduce tax reform to encourage private sector } \\
\text { and lighten administrative burden. }\end{array}$ & $\begin{array}{l}\text { Tax reform legislation under consideration by } \\
\text { parliament. }\end{array}$ \\
\hline \multicolumn{2}{|c|}{ Financial Sector Policy } \\
\hline $\begin{array}{l}\text { Introduce a credit registry and pass pending } \\
\text { financial sector laws. }\end{array}$ & $\begin{array}{l}\text { Credit registry close to completion; financial } \\
\text { legislation still pending. }\end{array}$ \\
\hline $\begin{array}{l}\text { Continue strengthening of banking supervision } \\
\text { and regulation. }\end{array}$ & Banking supervision enhancement continuing. \\
\hline $\begin{array}{l}\text { Avoid state-owned rural development banks, at } \\
\text { minimum operate on commercial basis. }\end{array}$ & $\begin{array}{l}\text { Plans for government financial institutions } \\
\text { continue; authorities affirm plans to run on } \\
\text { commercial basis. }\end{array}$ \\
\hline \multicolumn{2}{|c|}{$\begin{array}{l}\text { Structural Reforms } \\
\end{array}$} \\
\hline Improve environment for private activity. & Key legislation and institutions still pending. \\
\hline Strengthen staff of MOF macroeconomic unit. & $\begin{array}{l}\text { MOF macroeconomic unit expanded, including } \\
\text { new external advisors. }\end{array}$ \\
\hline Strengthen statistical capacity. & Statistical capacity at BPA improving. \\
\hline
\end{tabular}

\section{A. How to Accelerate Growth and Reduce Poverty?}

\section{Background and Staff Views}

17. Achieving Timor-Leste's development objectives will be a long and challenging task, requiring well-targeted investment spending and a supportive institutional framework to encourage stronger private sector growth. The formal non-oil economy 
needs to expand at a quick pace, at least 8 percent annually, to support the rapidly growing population and prevent poverty from deepening. ${ }^{5}$ The private sector could be an important source of long-term growth and job creation, with considerable potential in sectors such as commercial agriculture (especially coffee), fisheries, and tourism, given under-utilized land and untouched coastlines. However, the non-oil economy is unlikely to expand significantly without greater public investment in infrastructure and human capital, and intensified structural reforms to improve the competitiveness of the business environment. Timor-Leste has weak infrastructure and shortcomings in education and health. In global surveys, it ranks especially poorly in telecommunications and transport infrastructure, and in ease of contract enforcement and property registration (Box 3). While the government has the financial resources to increase needed investment spending, administrative capacity is weak and the economy's absorptive capacity is limited.
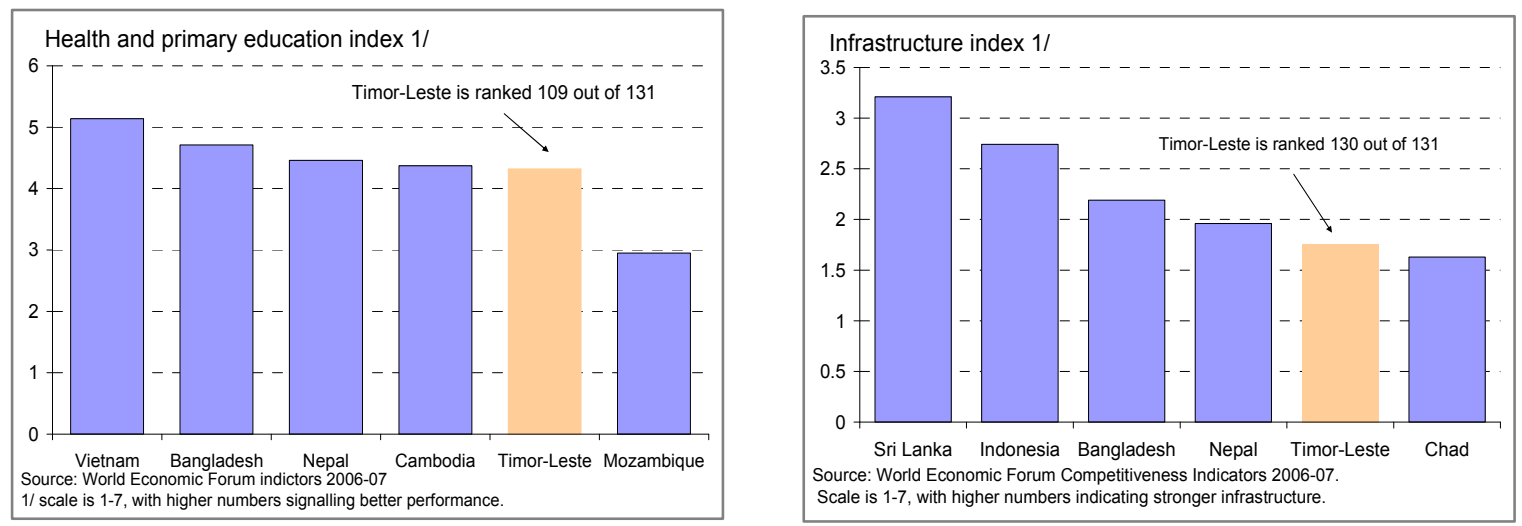

\begin{tabular}{|c|c|c|c|c|c|c|c|c|}
\hline \multicolumn{9}{|c|}{ Doing Business Survey (Rankings Among 178 Countries) $1 /$} \\
\hline & $\begin{array}{c}\text { Overall } \\
\text { Rank }\end{array}$ & $\begin{array}{l}\text { Starting a } \\
\text { Business }\end{array}$ & $\begin{array}{l}\text { Dealing with } \\
\text { Licenses }\end{array}$ & $\begin{array}{l}\text { Registering } \\
\text { Property }\end{array}$ & $\begin{array}{l}\text { Getting } \\
\text { Credit }\end{array}$ & $\begin{array}{l}\text { Protecting } \\
\text { Investors }\end{array}$ & $\begin{array}{l}\text { Enforcing } \\
\text { Contracts }\end{array}$ & $\begin{array}{l}\text { Closing a } \\
\text { Business }\end{array}$ \\
\hline Timor-Leste & 168 & 140 & 100 & 178 & 170 & 122 & 178 & 178 \\
\hline Low-income Asia Pacific (avg.) & 99 & 79 & 66 & 105 & 125 & 95 & 94 & 138 \\
\hline Total Asia Pacific (avg.) & 77 & 82 & 66 & 87 & 99 & 77 & 86 & 98 \\
\hline
\end{tabular}

\section{Staff supported the existing strategy of stepping-up public and private investment, noting the need for consistency with implementation capacity.}

- $\quad$ An updated and costed NDP should inform decisions on how to allocate TimorLeste's resources, with projects prioritized according to the social rate of return, a carefully sequenced timetable, and a framework for monitoring performance. Completion of the NDP should be fast-tracked to support the 2009 budget.

\footnotetext{
${ }^{5}$ Population growth is estimated at about 3.5 percent a year and youth unemployment in Dili at 40 percent. Almost 45 percent of the population is under 15 years of age.
} 


\section{Box 3. Exchange Rate Assessment}

Competitiveness could be enhanced by addressing the significant structural disincentives to private investment.

The exchange rate does not appear to be out of line with fundamentals. The NEER is close to its 2004 level. While the coreCPI-based REER has depreciated relative to 2003-05 level, headline-CPI-based REER has remained relatively unchanged from 2006. Much of the REER decline can be attributed to low core inflation relative to Indonesia - the main trading partner-with price pressures so far mainly resulting from supply-side factors.

\section{However, competitiveness and} institutional indicators give a more mixed picture. Global surveys consistently rank Timor-Leste as having one of the most uncompetitive business environments. Anecdotal evidence suggests that average wages are relatively high, given TimorLeste's low income and high unemployment. However, private sector wages appear relatively unchanged over the past several years.

\section{Timor Leste's overall policies appear consistent with the maintenance of}

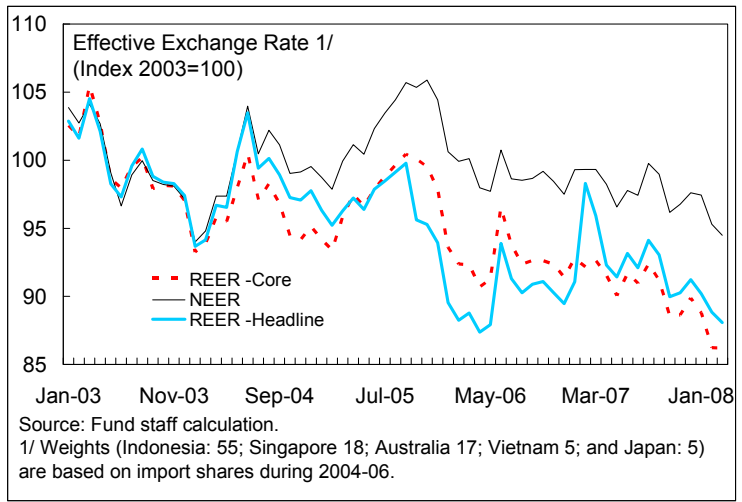

\begin{tabular}{|c|c|c|c|}
\hline \multicolumn{4}{|c|}{ Assessment of Business Climate, 2007} \\
\hline \multicolumn{2}{|c|}{ Doing Business } & \multicolumn{2}{|c|}{ Global Competitiveness Index } \\
\hline & $\begin{array}{r}\text { Rank } \\
\text { among }\end{array}$ & & $\begin{array}{r}\text { Rank } \\
\text { among }\end{array}$ \\
\hline Countries & 178 & Countries & 131 \\
\hline Papua New Guinea & 84 & Thailand & 28 \\
\hline Vietnam & 91 & Indonesia & 54 \\
\hline Sri Lanka & 101 & Vietnam & 68 \\
\hline Bangladesh & 107 & Sri Lanka & 70 \\
\hline Nepal & 111 & Philippines & 71 \\
\hline Indonesia & 123 & Bangladesh & 107 \\
\hline Philippines & 133 & Cambodia & 110 \\
\hline Cambodia & 145 & Nepal & 114 \\
\hline Timor-Leste & 168 & Timor-Leste & 127 \\
\hline $\begin{array}{l}\text { Sources: World Bank, } \\
\text { Forum. }\end{array}$ & Developn & nt Indicators; and $\mathrm{W}$ & \\
\hline
\end{tabular}
scope for increased government spending and domestic consumption to reduce current account surpluses over the medium term. The sustainable current account balance is computed, similarly to the sustainable fiscal spending limits, as the difference between oil/gas income and the estimated sustainable income from oil/gas wealth (Box 1). Results indicate that the current account surpluses in 2007-08 are above their long-run sustainable level (reflecting temporary factors - the sharp increase in income and more gradual change in consumption), implying space for the increased spending and consumption. While the current REER may be undervalued, the degree may be small, given the high expected import content of future domestic demand. As spending increases, the gap between the actual current account surplus and the sustainable level is expected to narrow and then reverse. Sensitivity analysis indicates that lower oil/gas revenues would further reduce the gap. 
- $\quad$ Structural reforms to increase productivity and spur private sector activity should be expedited, in particular a pending land law to provide a framework for land ownership, titling, and registration, and simplified business regulations, along with judicial reform to help courts address commercial disputes.

- $\quad$ The tax reform (Box 4), now being considered in Parliament, is a welcome step forward. It also presents an opportunity to remove tax incentives under the investment laws, which would be made redundant and have proved difficult to enforce.

\section{Box 4. Tax Reform}

Against the background of the significant increase in oil/gas revenue and reduced need for non-oil taxation, the government plans to significantly reduce tax rates, lower compliance costs, and streamline regulations to encourage private activity. The reform, designed with FAD and LEG technical assistance, would maintain a basic system so that revenue could be raised in the future if needed. It includes: ${ }^{1}$

- $\quad$ Reducing income tax rates from 30 to 10 percent, with high thresholds that exempt most wage earners and full expensing of fixed assets for businesses.

- $\quad$ Reducing import duties and sales tax rates from 6 to $2 \frac{1}{2}$ percent and service tax rates from 12 to 5 percent.

As a result, non-oil tax revenue is estimated to decline from about 10 percent to 5 percent of non-oil GDP.

${ }^{1}$ See 2006 Article IV Selected Issues paper on tax reform.

\section{Authorities' Plans and Views}

19. The authorities agreed with the need for increased public investment, which was the focus of their longer-term strategy. They pointed to plans to address shortcomings in infrastructure and human capital, including wide-ranging investment in electricity generation, road building, water supply, agriculture, ports, housing, health, and education. These sectors would all be covered in an updated and fully-costed NDP to be prepared over the next few months.

20. The authorities also agreed that long-term growth and job creation would need to come from the private sector. They are committed to creating an enabling environment, including by passing the land law this year. 


\section{B. How Much Should the Government Spend to Promote Growth Without Risking Stability?}

\section{Background and Staff Views}

21. The challenges presented by the civil unrest, combined with underlying development needs, point to the need for increased spending; however large prospective step-increases in the MYBU raise concerns regarding inflation and waste. Through 2007, combined government and donor expenditure have not had a major inflationary impact, reflecting the large import content of public spending, unused labor resources, and below potential GDP growth. However, even allowing for budget execution shortfalls, the size and composition of expected spending increases in 2008 could create significant price pressures, particularly if largely not contributing to improved productivity. Staff projects a 50 percent increase in cash spending, weighted toward current expenditure. As a result, the absorption capacity of the domestic economy could come under significant strain with bottlenecks emerging, such as in port capacity, construction, and the skilled labor market. At the same time, in a

\begin{tabular}{|c|c|c|c|c|c|c|c|}
\hline \multicolumn{8}{|c|}{$\begin{array}{l}\text { Central Government Budget } \\
\text { (In percent of non-oil GDP) }\end{array}$} \\
\hline & \multicolumn{2}{|c|}{$2006 / 07$} & \multicolumn{2}{|c|}{$2007 \mathrm{H} 2$} & \multicolumn{3}{|c|}{2008} \\
\hline & Budget & Act. & Budget & Act. & Budget & IYBU 1/ & Proj. \\
\hline Revenue & 203 & 289 & 291 & 350 & 291 & 423 & 424 \\
\hline of which oil and gas & 189 & 275 & 281 & 340 & 287 & 417 & 417 \\
\hline Expenditure (commitments) & 86 & 71 & 55 & 52 & 72 & 105 & 86 \\
\hline Current & 48 & 44 & 52 & 44 & 53 & 76 & 66 \\
\hline Capital & 38 & 27 & 3 & 8 & 19 & 29 & 21 \\
\hline Expenditure (cash) $2 /$ & $\ldots$ & 43 & $\ldots$ & 31 & $\ldots$ & $\ldots$ & 61 \\
\hline Current & $\ldots$ & 37 & $\ldots$ & 30 & $\ldots$ & $\ldots$ & 52 \\
\hline Capital & $\cdots$ & 6 & $\ldots$ & 1 & $\cdots$ & $\cdots$ & 9 \\
\hline \multicolumn{8}{|l|}{ Memorandum items: } \\
\hline Cash opening balance $3 /$ & 63 & 26 & 115 & 115 & 38 & 38 & 38 \\
\hline Carry-over opening balance $3 / 4$ / & 13 & 13 & 59 & 59 & 20 & 20 & 20 \\
\hline Carry-over spending $4 /$ & 13 & 5 & 59 & 22 & 20 & 20 & 10 \\
\hline Total cash spending 4/ & 98 & 48 & 114 & 53 & 92 & 125 & 71 \\
\hline 'Sustainable' spending & 92 & $\ldots$ & 77 & $\ldots$ & 66 & 90 & 90 \\
\hline \multicolumn{8}{|c|}{$\begin{array}{l}\text { Source Timor-Leste authorities and staff estimates } \\
1 / \text { Preliminary, as of mid-May. Cost of rice subsidies (5.8 percent of non-oil GDP) } \\
\text { is included in current expenditure on a net basis. } \\
2 \text { / Cash spending of current budget. } \\
3 \text { / Figures for } 2007 \mathrm{H} 2 \text { are higher because of comparing to half-year GDP. } \\
\text { 4/ Figures in budget columns assume full cash execution, also of carry-over. }\end{array}$} \\
\hline
\end{tabular}
break from past policy, for the first time the authorities are considering external borrowing to finance large-scale infrastructure development.

22. While understanding the need to increase spending, increases should be better prioritized and targeted to minimize waste and inflation. Staff recommended:

- $\quad$ Tempering expectations and planned spending increases in line with implementation capacity, while emphasizing investment in infrastructure and human capital consistent with a prioritized NDP.

- $\quad$ Closely monitoring price developments for signs of emerging supply constraints, with mid-year budget reviews being an opportunity to manage excessive demand pressures. 
- $\quad$ Targeting humanitarian relief to the most needy and minimizing disruptions of private markets, designing an exit strategy to help avoid the creation of long-term entitlements, and supporting domestic agricultural production.

- $\quad$ Considering public sector pay increases together with performance-improving reforms. The decision to delay a proposed new pay and grading system, pending further study, was welcomed. However, a new $13^{\text {th }}$ month payment and continued rice allowances to civil servants represent an effective pay increase of over 20 percent to an already privileged group.

\section{Staff recommended addressing obstacles to budget execution, especially in investment spending:}

- $\quad$ Budget execution would be enhanced by an updated NDP and medium-term fiscal framework. Streamlining payment procedures and accelerating training and capacity building would allow increased delegation of financial management and procurement authority to line ministries.

- $\quad$ Cash grants for specific purposes (e.g., education abroad or humanitarian aims) could contribute to improved results, provided done without weakening fiduciary standards.

- $\quad$ A move to a cash-based budget system that limits expenditure carry-overs to major capital outlays and more comprehensive reporting on past budget execution would enhance transparency.

\section{Staff viewed that the petroleum fund arrangements remain appropriate:}

- $\quad$ The petroleum fund helps promote macroeconomic stability by separating budget spending from volatile revenue flows and emphasizing fiscal sustainability. By mandating a high level of transparency and investing funds abroad, it also promotes accountability. These mechanisms should help shield Timor-Leste from the natural resource "curse."

- The existing framework is flexible enough to allow the government to spend more than sustainable income in a given year, as long as the justification and consequences are presented to parliament, helping ensure an open consultation process.

- The current sustainable income levels leave ample room to meet immediate social, security, and development needs.

\section{Authorities' Plans and Views}

25. Timor-Leste's petroleum wealth has enabled the government to respond to needs for higher spending. While medium-term development objectives call for increased investment spending, the civil unrest and more recent food price increases require urgent intervention. Immediate demands require higher spending and have skewed the budget 
towards current expenditure. However, many new appropriations are one-off. Inflation risks are manageable, especially given the large import content of government spending.

26. The authorities stressed that the long-term focus remains on investment. An updated national development plan would soon be ready, emphasizing human capital and infrastructure. The authorities also reaffirmed their commitment to the basic principles of the petroleum fund arrangement, although noting plans to broaden the investment universe to increase returns.

27. The authorities also underscored that reform efforts would soon improve budget execution. Capital projects would rely to a large extent on international and private sector expertise for design and implementation. They observed that their new government had been in office less than one year and faced a starting point of very low administrative capacity. In that light, the authorities noted their appreciation for assistance provided by development partners, including the Fund and the World Bank for capacity building in planning and financial management. In addition, several donors, including the AsDB, were devoting significant technical assistance to infrastructure development.

28. The pros and cons of external borrowing were being carefully weighed. Although there is financial equivalence between foreign borrowing and drawing resources from the petroleum fund, it could be more cost effective to use concessional loans. Additionally, if technical assistance is attached, borrowing could also assist implementation of major infrastructure projects. The authorities also noted that care would be given to avoid unproductive investments and minimize inflation pressures, and that debt management capacity would need to be created.

\section{Is the Current Exchange Rate Regime and Level Appropriate?}

\section{Background and Staff Views}

29. Staff noted that the use of the U.S. dollar has supported macroeconomic stability by providing a credible nominal anchor and helping keep inflation in check. In addition, although institutional capacity at the Banking and Payments Authority (BPA) has been considerably strengthened over the past several years, management of exchange rate and monetary policy would strain existing capabilities. Staff also noted that the absence of monetary policy tools places even greater importance on ensuring that fiscal pressures and structural constraints do not undermine competitiveness.

30. Overall, the exchange rate does not appear fundamentally out of line with its long-term equilibrium (Box 3). While the REER has depreciated moderately, other indicators of competitiveness are mixed. With the nominal effective exchange rate broadly unchanged from 2004, the REER has depreciated mainly due to Timor-Leste's record of relatively low inflation, implying that price competitiveness has not worsened with the growing petroleum revenue of the past few years. Indeed, a greater obstacle to competitiveness and growth is likely to be the structural factors where Timor-Leste fares poorly relative to comparators. Timor-Leste's poor data quality precludes the standard 
empirical assessment of the exchange rate level; however, a broad forward view suggests that policies appear consistent with long-term external stability.

\section{Authorities’ Plans and Views}

\section{The authorities agreed that the existing exchange rate regime remains} appropriate. They concurred that stronger institutional capacity would need to be established before planning the introduction of a national currency. They also reaffirmed their intention to address the structural impediments to competitiveness and remain attentive to emerging inflationary pressures.

\section{How Best to Promote Financial Intermediation?}

\section{Background and Staff Views}

32. Economic growth prospects would benefit from a strengthened financial sector. However, staff pointed out that the level of the credit to the private sector in Timor-Leste is not exceptionally low relative to comparators and that the high level of NPLs is not likely a systemic risk, as all three commercial banks are branches of established foreign banks, with stated intentions to expand outside of Dili. Indeed, fiscal risks appear small, given high levels of provisioning and of liquidity. Nevertheless, more could be done, with staff recommending a focus on building a supportive environment for a stable financial system based on sound business principles, including:

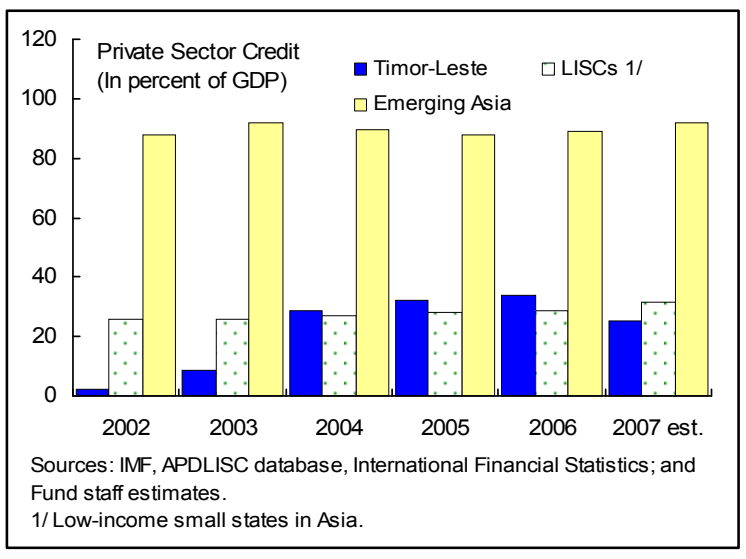

- $\quad$ Enacting critical long-pending financial sector legislation, including the law to transform the BPA into a full-fledged central bank, as well as banking, payments system, and anti-money laundering legislation.

- $\quad$ Facilitating loan recovery and contract enforcement by finalizing land titling legislation and procedures, and introducing alternative dispute mechanisms based on traditional systems.

- $\quad$ Continuing strengthening of banking supervision.

- In light of well-known problems encountered by development banks globally, ensuring that public sector involvement in the financial sector be on commercial terms and supervised under domestic law. 


\begin{tabular}{|c|c|c|c|c|c|c|c|c|c|}
\hline \multicolumn{10}{|c|}{ Timor-Leste: Banking Indicators (in percent) } \\
\hline & \multirow{2}{*}{$\begin{array}{c}2003 \\
\text { Q4 }\end{array}$} & \multirow{2}{*}{$\begin{array}{c}2004 \\
\text { Q4 }\end{array}$} & \multirow{2}{*}{$\begin{array}{c}2005 \\
\text { Q4 }\end{array}$} & \multirow{2}{*}{$\begin{array}{c}2006 \\
\text { Q4 }\end{array}$} & \multicolumn{4}{|c|}{2007} & \multirow{2}{*}{$\begin{array}{c}2008 \\
\text { Q1 }\end{array}$} \\
\hline & & & & & Q1 & Q2 & Q3 & Q4 & \\
\hline Capital adequacy ratio 1/ & 227.9 & 226.5 & 121.2 & 189.8 & 189.0 & 167.1 & 134.8 & 107.0 & 87.6 \\
\hline Net profit/average assets & -0.4 & 2.3 & 2.6 & -21.3 & 0.5 & 1.3 & 1.6 & 1.7 & 0.6 \\
\hline NPLs/total loans & 6.3 & 5.4 & 12.5 & 27.8 & 29.9 & 32.7 & 30.4 & 30.2 & 28.2 \\
\hline Total provisions/NPLs & 2.2 & 5.8 & 23.2 & 181.6 & 169.6 & 158.7 & 165.9 & 178.9 & 187.2 \\
\hline Liquid assets/total assets & 74.3 & 36.0 & 34.8 & 47.9 & 55.4 & 61.4 & 63.0 & 71.3 & 69.7 \\
\hline
\end{tabular}

\section{Authorities' Plans and Views}

33. The authorities agreed that the slow-down in credit growth since mid-2004 and the increase in bank's NPLs were concerns. They pointed to ongoing efforts to strengthen the financial system, including a central credit information registry to be launched shortly and continued enhancements in banking supervision. Banks were seen as reluctant to take risks and charging excessive interest but, nevertheless, with a growing economy, the authorities expected that credit would soon start to pick up.

34. In addition, the authorities noted the need to expand access to financial services, especially in the districts. To do so, the government plans to take over the largest microfinance bank and to create a National Development Bank, but plans for the latter were still at an early stage. The authorities noted their determination to prevent political influence and to ensure that loans are evaluated on commercial terms.

\section{E. Other Issues}

35. Despite some progress, macroeconomic analysis continues to be hampered by the absence of good quality data, particularly for the national accounts. Monetary aggregates and financial data are now available in the IMF's International Financial Statistics. Good progress has also been made in compilation of balance of payments statistics, since its transfer to the BPA, and the first estimates will soon be published. The staff recommended that adequate resources be provided to compile the national accounts.

36. Timor-Leste maintains an open trade regime, with a uniform duty on imports and no quantitative restrictions. 


\section{Staff Appraisal}

37. Timor-Leste has a good foundation for economic development. Civil unrest has caused setbacks and growth has not yet been sufficient to reduce widespread poverty. Nevertheless, a sound fiscal and monetary framework has ensured macroeconomic stability and the newfound petroleum wealth offers the potential of a substantial increase in living standards.

38. The strategy set out in the original National Development Plan remains valid. This includes the long-term oil/gas revenue saving policy supported by the petroleum fund; well-targeted development spending; a monetary and exchange rate regime that preserves macroeconomic stability; and a supportive environment for private investment and activity. The plan to update the NDP is an opportunity to reinforce these objectives and should be fast-tracked.

39. Greater efforts are needed to encourage private investment and activity. Staff is encouraged by plans to enact a land law this year, the absence of which has been one of the greatest impediments to progress. The planned tax reform is also a welcome step. However, more could be done to simplify business regulations and to improve the judicial system.

40. Stepping up investment will be key to growth and poverty reduction, particularly for infrastructure and human capital. Financial resources are available but achievable outcomes are constrained by low administrative capacity and a difficult starting point, highlighting the need to prioritize.

41. Addressing pressing security and humanitarian needs is necessary, but the spending should be well-prioritized and carefully managed. Large increases in government expenditure intensify the need to guard against unproductive spending and inflationary pressures through careful planning and monitoring. The overall level of appropriations should be in line with implementation and absorption capacities.

42. Large spending increases planned for the mid-year 2008 budget, despite still low administrative and absorptive capacity, raise concerns about potential waste and pressure on prices. The increased spending appears beyond what can be soundly executed, including the large ad-hoc wage increases. Care should also be given to avoid the creation of long-term entitlements.

43. Achieving good results depends on overcoming impediments to budget execution, particularly for capital projects. International outsourcing would help speed up implementation. Outcomes would be enhanced by more realistic planning, streamlining of payment procedures, and a move to cash-based budgeting. Proposals to begin external borrowing should be carefully weighed and transparently analyzed to ensure adequate concessionality, a clear net positive rate of return, and consistency with the NDP and macroeconomic stability. 
44. The petroleum fund is a cornerstone for sound management of the country's resources. The fund provides a powerful tool for promoting fiscal sustainability and macroeconomic stability. By smoothing budget spending, investing the remainder abroad, and mandating a high level of transparency, it shields against the "oil curse" afflicting other resource rich countries. The focus on sustainable income encourages prioritization. The model is also flexible and allows for higher levels of spending, if justified. When revisiting the petroleum fund law to enhance the expected rate of return, the authorities are urged to preserve the basic principles of this framework.

45. The current level of the exchange rate appears broadly consistent with its equilibrium level. The use of the U.S. dollar has served the economy well by providing a credible nominal anchor for price stability, although it places greater emphasis on ensuring that fiscal pressures do not undermine macroeconomic stability. Stronger institutional capacity is needed before considering a move to introduce a national currency.

46. Initiatives to strengthen the financial sector are welcomed, including progress on a credit registry and strengthening banking supervision. Additional efforts are needed on pending financial sector legislation and creation of an alternative dispute mechanism, while any government participation in the financial system should be on commercial terms and supervised under domestic banking laws.

47. Progress on compilation of financial and balance of payments statistics is welcome, but better monitoring of real sector activity is needed. Creating capacity to compile national accounts should be a priority.

48. It is proposed that the next Article IV consultation be conducted on the standard 12-month cycle. 
Figure 1. Timor-Leste: Regional and Global Comparisons 1/

Six years after independence, standards of living in Timor Leste remain low compared to those in other developing regions in the world...
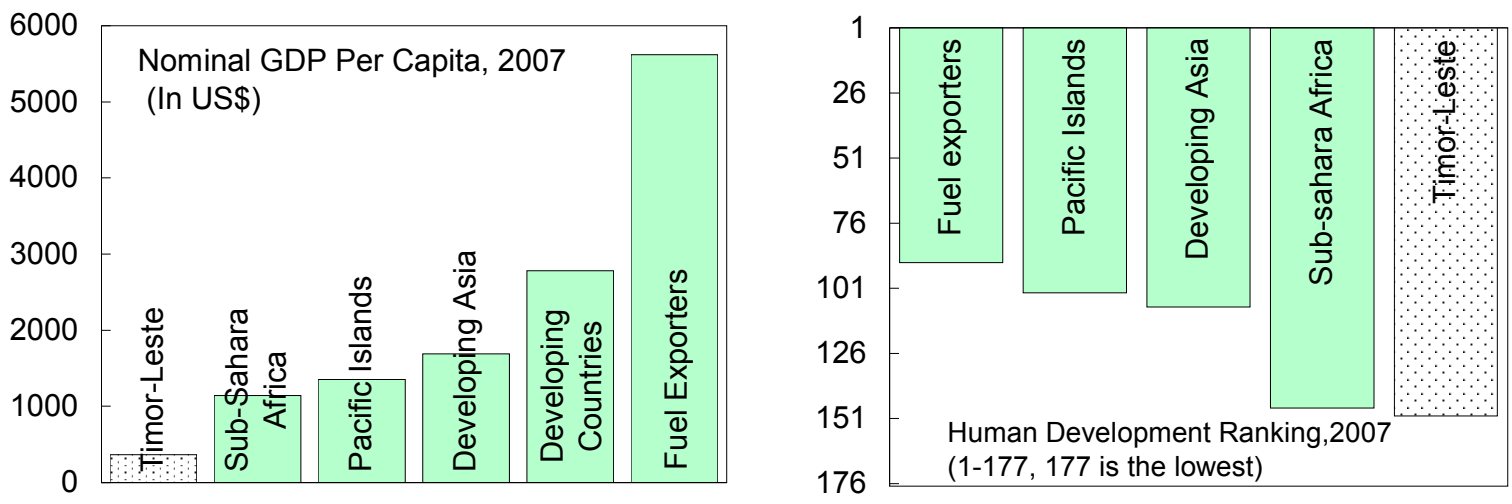

...despite good macroeconomic management, reflected in low inflation and the absence of external public debt.
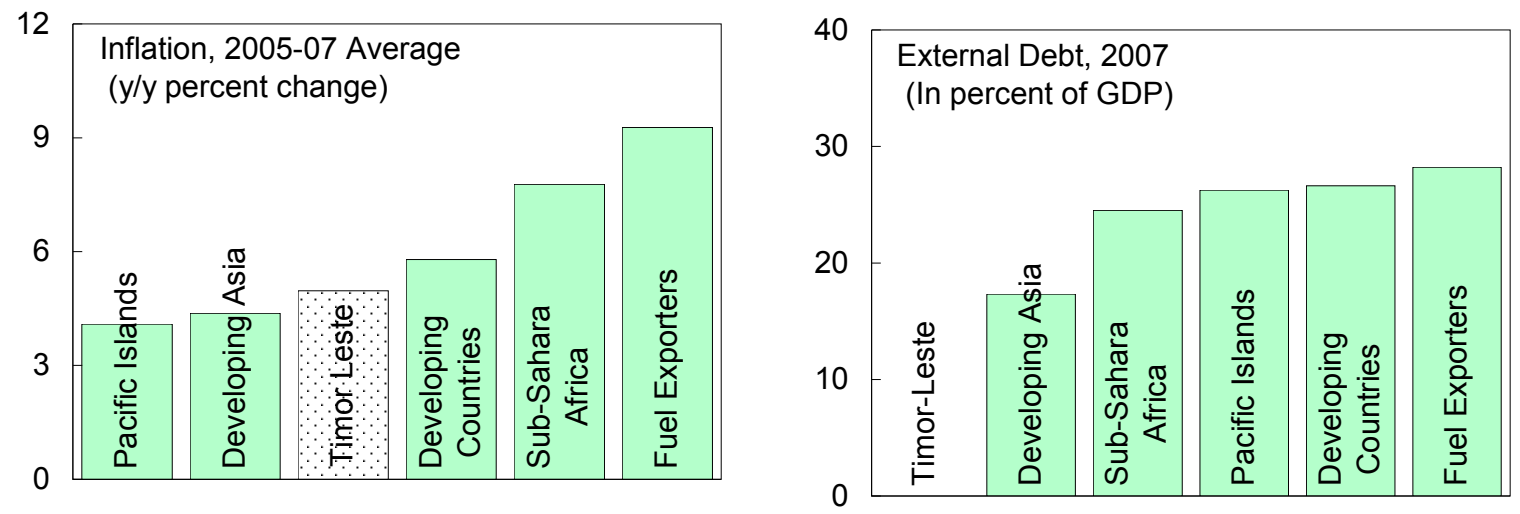

However, large per-capita oil reserves provide policy makers with significant opportunities to strengthen growth prospects, while maintaining a stable macroeconomic environment.2/
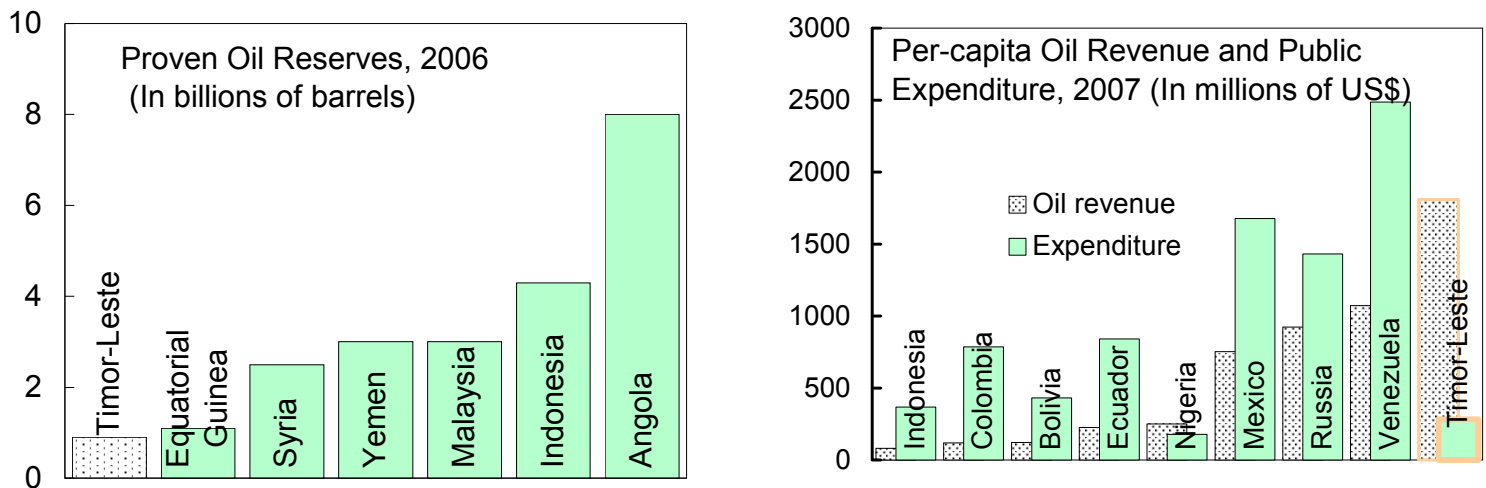

Sources: Authorities; UN, Human Development Indicators, 2007/08; IMF, World Economic Outlook and FAD-DEME databases; PennWell Corporation, Oil \& Gas Journal, December, 2006; and Fund staff estimates.

1/ For Timor-Leste, calculations in non-oil GDP.

2/ Bayu Undan field only. When production starts in the Greater Sunrise field, total reserves will increase significantly. 
Figure 2. Timor Leste: Recent Macroeconomic Developments

Civil unrest halted the nascent recovery in non-oil GDP in 2006 and has subdued the recovery. Rising global food prices have pushed up inflation.
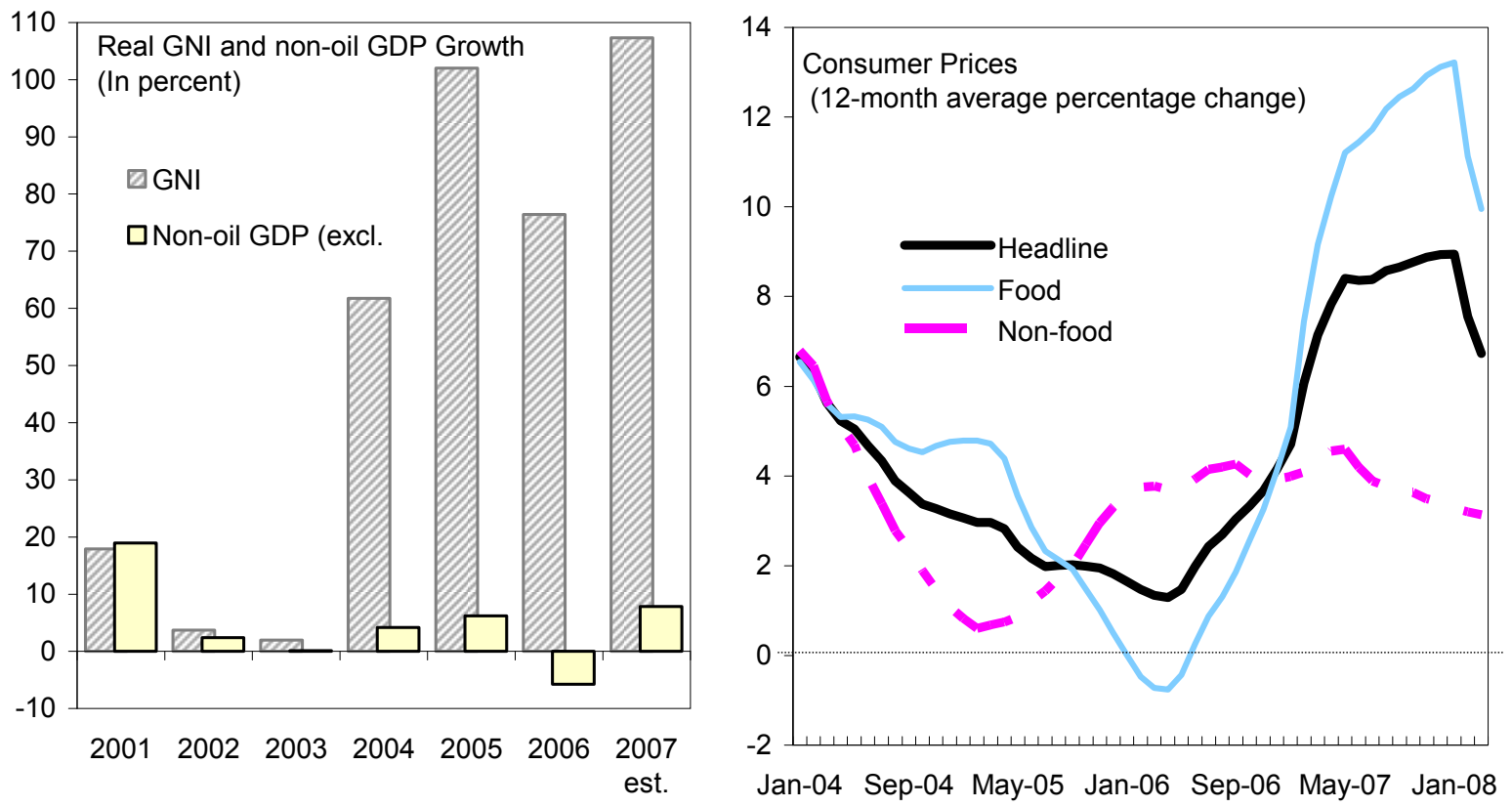

Growing oil/gas revenue has boosted national income and the current account surplus. From a relatively small base, non-oil exports have continued to grow.
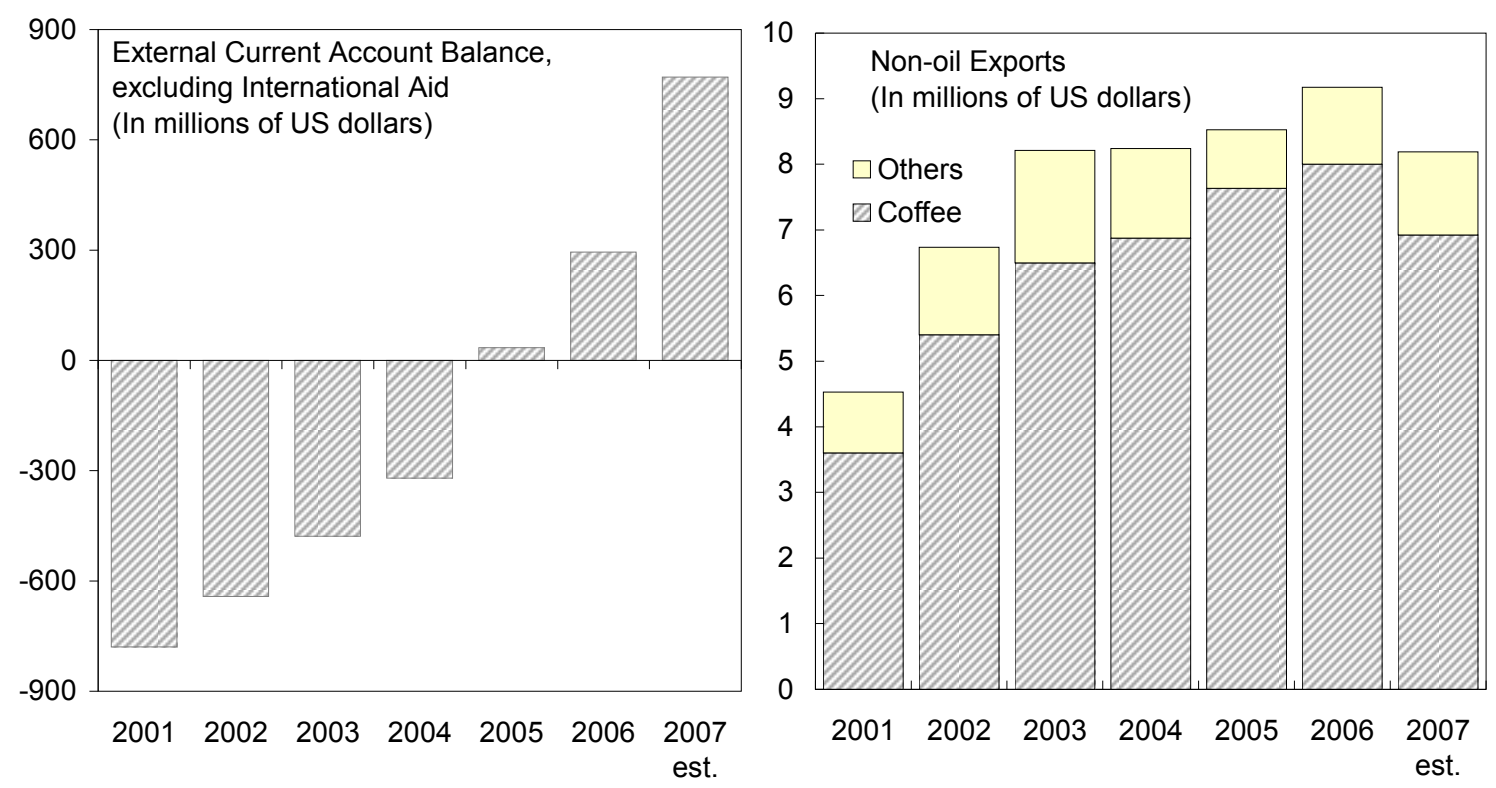

Sources: Timor-Leste authorities; and Fund staff estimates and projections. 
Figure 3: Timor Leste: Medium-term Baseline Scenario
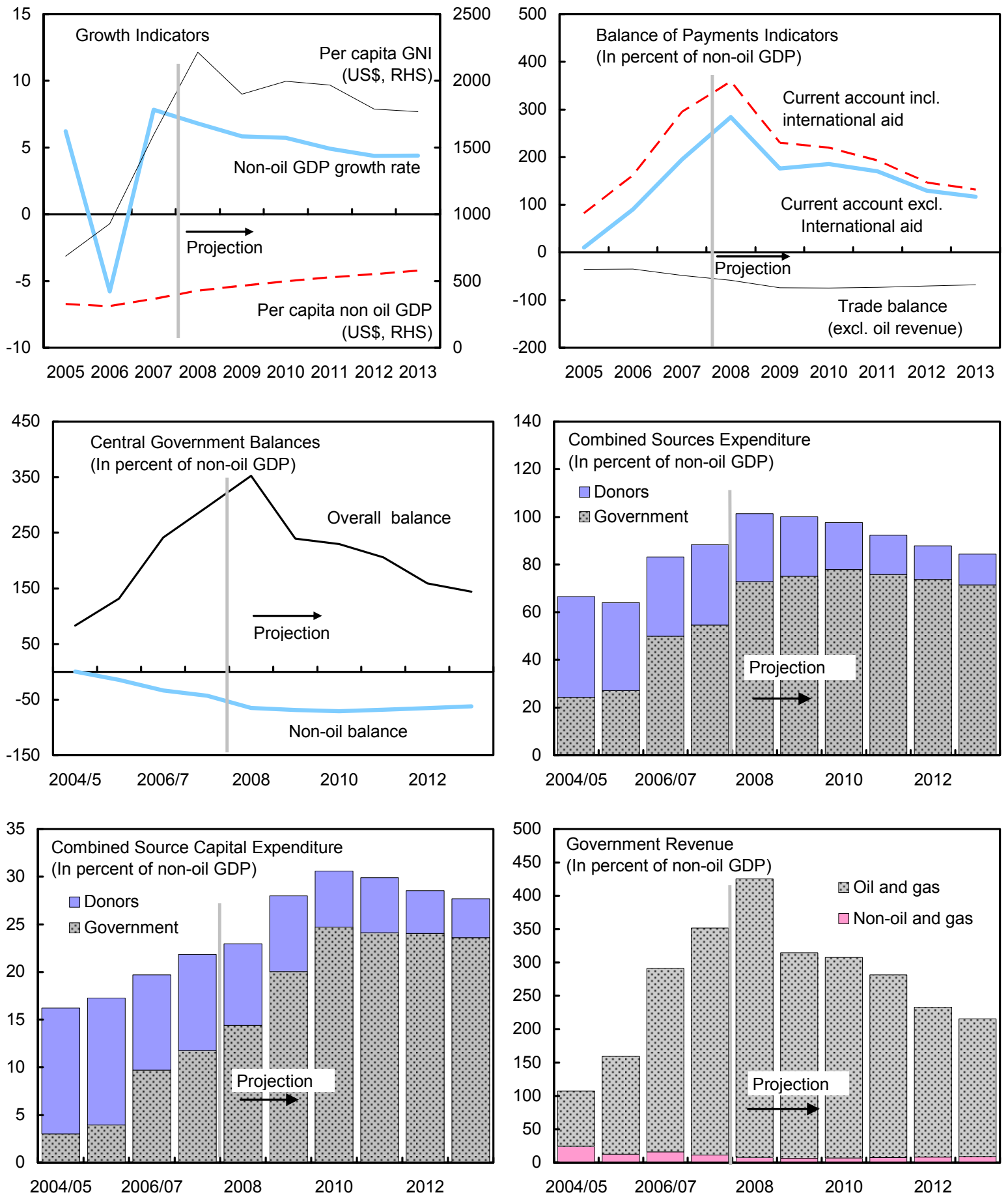

Sources: Country authorities and Fund staff estimates. 
Table 1. Timor-Leste: Selected Social Indicators 1/

\begin{tabular}{|c|c|c|c|}
\hline & $\begin{array}{l}\text { Timor- } \\
\text { Leste }\end{array}$ & $\begin{array}{l}\text { East Asia } \\
\text { and Pacific } \\
\text { Island } \\
\text { countries }\end{array}$ & $\begin{array}{c}\text { Low } \\
\text { income } \\
\text { countries }\end{array}$ \\
\hline Gross national income per capita (US\$) 2/ & 1,647 & 1,856 & 649 \\
\hline GDP per capita (US\$) 2/ & 378 & 4,363 & 1,884 \\
\hline Area (in thousands of square kilometers) & 15 & & \\
\hline \multicolumn{4}{|l|}{ Demography } \\
\hline Total population (in millions) & 1.015 & 1,899 & 2,420 \\
\hline Population growth (in percent) 3/ & 4.0 & 0.9 & 1.9 \\
\hline \multicolumn{4}{|l|}{ Life expectancy and mortality } \\
\hline Life expectancy at birth (years) & 57 & 71 & 60 \\
\hline Male & 56 & 69 & 59 \\
\hline Female & 58 & 73 & 62 \\
\hline Infant mortality (per thousand live births) & 47 & 24 & 74 \\
\hline Under 5 mortality rate (per thousand live births) & 55 & 29 & 112 \\
\hline \multicolumn{4}{|l|}{ Education 4/ } \\
\hline Literacy rate (in percent) 5/ & 50 & 91 & 61 \\
\hline Male & 54 & 95 & 72 \\
\hline Female & 45 & 87 & 50 \\
\hline Gross primary school enrollment rate (in percent) & 99 & 111 & 102 \\
\hline \multicolumn{4}{|c|}{ Health } \\
\hline \multicolumn{4}{|c|}{ Immunization rate (in percent of children aged 12 to 23 months) } \\
\hline Measles & 64 & 89 & 69 \\
\hline DPT & 67 & 89 & 68 \\
\hline \multicolumn{4}{|l|}{ Other indicators $6 /$} \\
\hline The population below the poverty line & $407 /$ & $\ldots$ & $\ldots$ \\
\hline Households with access to electricity & $267 /$ & $\ldots$ & $\ldots$ \\
\hline Population with access to improved water source 8/ & 58 & 79 & 75 \\
\hline
\end{tabular}

Sources: World Bank, World Development Indicators; and Country authorities.

1/ Data are for 2006, unless otherwise indicated.

2/ Timor Leste figures are for 2007. GDP refers to non-oil GDP at market prices. For comparators, GNI is calculated using Atlas method and GDP using PPP exchange rate.

3/ Average growth over 2000-2006.

4/ Figures are for 2005.

5/ For ages 15 and above.

6/ In percentage share of the total.

7/ Figures are for 2001.

8/ Figures are for 2004. 
Table 2. Timor-Leste: Selected Economic Indicators, 2003-08

\begin{tabular}{|c|c|c|c|c|c|c|}
\hline & 2003 & 2004 & 2005 & 2006 & $\begin{array}{c}2007 \\
\text { Prel. }\end{array}$ & $\begin{array}{c}2008 \\
\text { Proj. }\end{array}$ \\
\hline \multicolumn{7}{|l|}{ Output and prices } \\
\hline GNI at current prices (US\$ million) & 318 & 459 & 696 & 974 & 1,725 & 2,464 \\
\hline Non-oil GDP at current prices (US\$ million) & 298 & 309 & 332 & 327 & 396 & 473 \\
\hline Real non-oil GDP growth (percentage change) & 0.1 & 4.2 & 6.2 & -5.8 & 7.8 & 6.8 \\
\hline Including United Nations 1/ & -6.2 & 0.4 & 2.3 & -3.4 & 16.2 & 4.7 \\
\hline Inflation (percentage change, end-period) $2 /$ & 4.2 & 2.5 & 1.0 & 6.7 & 7.6 & 9.0 \\
\hline \multirow[t]{2}{*}{ Inflation (percentage change, period average) 2/ } & 7.2 & 3.2 & 1.8 & 4.1 & 8.9 & 9.0 \\
\hline & \multicolumn{6}{|c|}{ (In percent of non-oil GDP) } \\
\hline \multicolumn{7}{|l|}{ Investment-saving balance } \\
\hline Gross investment 3/ & 29 & 21 & 21 & 21 & 28 & 31 \\
\hline Gross national savings & 22 & 29 & 103 & 183 & 323 & 387 \\
\hline External savings & 8 & -9 & -82 & -162 & -295 & -357 \\
\hline \multicolumn{7}{|l|}{ Central government budget 4 / } \\
\hline Revenues & 35 & 105 & 157 & 289 & 350 & 424 \\
\hline Domestic revenues & 10 & 12 & 10 & 11 & 10 & 7 \\
\hline Oil/gas revenues & 14 & 83 & 146 & 275 & 340 & 417 \\
\hline Grants & 11 & 11 & 0 & 3 & 0 & 0 \\
\hline Expenditure (cash basis) & 21 & 22 & 26 & 48 & 53 & 71 \\
\hline Recurrent expenditure & 20 & 19 & 21 & 39 & 41 & 57 \\
\hline Capital expenditure & 1 & 3 & 5 & 9 & 12 & 14 \\
\hline Overall balance & 14 & 83 & 131 & 242 & 297 & 352 \\
\hline Non-oil fiscal balance & 0 & 0 & -16 & -33 & -43 & -65 \\
\hline Public debt & 0 & 0 & 0 & 0 & 0 & 0 \\
\hline Cumulative oil/gas savings & 4 & 5 & 112 & 310 & 527 & 810 \\
\hline \multicolumn{7}{|l|}{ Combined sources fiscal operations 4/ 5/ } \\
\hline Domestic revenue and budget grants & 23 & 25 & 13 & 16 & 12 & 8 \\
\hline Expenditure & 68 & 67 & 64 & 83 & 88 & 101 \\
\hline Recurrent expenditure & 52 & 50 & 47 & 64 & 66 & 78 \\
\hline Capital expenditure & 16 & 16 & 17 & 20 & 22 & 23 \\
\hline Overall balance & -45 & -42 & -51 & -67 & -77 & -93 \\
\hline \multicolumn{7}{|l|}{ Money and credit } \\
\hline Broad money (end-period) 6/ & 21 & 21 & 23 & 31 & 36 & 40 \\
\hline \multirow[t]{2}{*}{ Net domestic assets (end-period) } & -15 & -38 & -24 & -3 & -44 & -24 \\
\hline & \multicolumn{6}{|c|}{ (In millions of U.S. dollars) } \\
\hline \multicolumn{7}{|l|}{ External sector } \\
\hline Current account excl. international assistance & -479 & -321 & 34 & 295 & 771 & 1333 \\
\hline Current account incl. international assistance & -23 & 26 & 273 & 531 & 1168 & 1689 \\
\hline Merchandise exports $7 /$ & 8 & 8 & 9 & 9 & 8 & 11 \\
\hline Merchandise imports & -130 & -129 & -125 & -123 & -200 & -309 \\
\hline \multirow[t]{2}{*}{ Overall balance } & 18 & 121 & -29 & -70 & 147 & 0 \\
\hline & \multicolumn{6}{|c|}{ (In percent of non-oil GDP) } \\
\hline Current account excl. international assistance & -161 & -104 & 10 & 90 & 195 & 282 \\
\hline Current account incl. international assistance & -8 & 9 & 82 & 162 & 295 & 357 \\
\hline Overall balance & 6 & 39 & -9 & -21 & 37 & 0 \\
\hline \multicolumn{7}{|c|}{ Sources: Data provided by the Timor-Leste authorities; and Fund staff estimates. } \\
\hline $\begin{array}{l}\text { 1/ Includes locally paid compensation of UN peacekeepi } \\
\text { 2/ Whole of the country CPI from } 2003 \text {. } \\
\text { 3/ Excludes oil/gas sector investment. } \\
\text { 4/ Fiscal years (July-June) up to FY2006/07 (in column } \mathrm{f} \\
\text { 5/ Includes autonomous agencies and quasi-fiscal exper } \\
\text { decline in } 2005 \text { reflects the creation of the petroleum fun } \\
6 \text { / Excludes currency holdings by the public, for which no } \\
\text { 7/ Excludes oil/gas revenue, which is recorded as incom }\end{array}$ & $\begin{array}{l}\text { calenda } \\
\text { terals an } \\
\text { Income } \\
\text { late to re }\end{array}$ & $\begin{array}{l}\text { ars from } \\
\text { the fund } \\
\text { ation of }\end{array}$ & $\begin{array}{l}\text { side the } \\
\text { donor gr }\end{array}$ & $\begin{array}{l}\text { govern } \\
\text { finance }\end{array}$ & $\begin{array}{l}\text { t budget. } \\
\text { scal defic }\end{array}$ & revenue \\
\hline
\end{tabular}


Table 3. Timor-Leste: Central Government Budget, FY2004/05-2008 1/

\begin{tabular}{|c|c|c|c|c|c|c|c|c|}
\hline & \multirow[t]{2}{*}{$2004 / 05$} & \multirow[t]{2}{*}{$2005 / 06$} & \multicolumn{2}{|c|}{$2006 / 7$} & \multirow{2}{*}{$\frac{2007 \mathrm{H} 2}{\text { Prel. }}$} & \multicolumn{3}{|c|}{2008} \\
\hline & & & Budget & Act. & & Budget & MYBU 7/ & Proj. \\
\hline & \multicolumn{8}{|c|}{ (In millions of US dollars, unless otherwise specified) } \\
\hline $\begin{array}{l}\text { Revenue } \\
\text { Domestic revenues }\end{array}$ & $\begin{array}{r}337 \\
37\end{array}$ & $\begin{array}{r}517 \\
34\end{array}$ & $\begin{array}{r}733 \\
39\end{array}$ & $\begin{array}{r}1,045 \\
40\end{array}$ & $\begin{array}{r}693 \\
20\end{array}$ & $\begin{array}{r}1,379 \\
21\end{array}$ & $\begin{array}{r}2,005 \\
30\end{array}$ & $\begin{array}{r}2,005 \\
31\end{array}$ \\
\hline Direct taxes & 11 & 9 & 8 & 12 & 7 & 3 & 10 & 11 \\
\hline Indirect taxes & 19 & 16 & 21 & 19 & 8 & 8 & 10 & 9 \\
\hline Nontax revenues and other & 7 & 9 & 10 & 9 & 6 & 9 & 11 & 12 \\
\hline Oil/gas revenues $2 /$ & 266 & 482 & 683 & 993 & 672 & 1,359 & 1,974 & 1,974 \\
\hline Tax revenues & 209 & 345 & 558 & 498 & 184 & 522 & 726 & 726 \\
\hline Royalties & 56 & 123 & 86 & 458 & 456 & 728 & 1,120 & 1,120 \\
\hline Interest & 1 & 13 & 40 & 37 & 32 & 109 & 129 & 129 \\
\hline Grants & 34 & 1 & 10 & 11 & 0 & 0 & 0 & 0 \\
\hline Expenditure (commitment basis) $3 /$ & 74 & 119 & 309 & 258 & 104 & 341 & 496 & 409 \\
\hline Recurrent expenditure & 62 & 77 & 172 & 159 & 88 & 250 & 358 & 311 \\
\hline Wages and salaries & 25 & 26 & 47 & 40 & 24 & 50 & 65 & 62 \\
\hline Goods and services & 31 & 46 & 94 & 83 & 39 & 121 & 150 & 127 \\
\hline Subsidies & 5 & 6 & 13 & 18 & 14 & 15 & 52 & 49 \\
\hline Transfers & 0 & 0 & 18 & 17 & 12 & 64 & 91 & 73 \\
\hline Capital expenditure and net lending 4/ & 12 & 42 & 137 & 99 & 16 & 91 & 139 & 99 \\
\hline Minor capital & 2 & 7 & 17 & 18 & 5 & 24 & 30 & 23 \\
\hline CDF & 9 & 25 & 113 & 79 & 5 & 60 & 92 & 65 \\
\hline Subsidies & 1 & 11 & 7 & 2 & 6 & 7 & 16 & 11 \\
\hline Overall balance (commitment basis) & 263 & 397 & 424 & 787 & 589 & 1,038 & 1,508 & 1,596 \\
\hline Expenditure (cash basis) 5/ & 70 & 93 & $\ldots$ & 173 & 105 & $\ldots$ & $\ldots$ & 338 \\
\hline Recurrent expenditure & 62 & 76 & $\ldots$ & 140 & 82 & $\ldots$ & $\ldots$ & 271 \\
\hline Wages and salaries & 25 & 26 & $\ldots$ & 40 & 24 & $\ldots$ & $\ldots$ & 62 \\
\hline Goods and services & 31 & 38 & $\ldots$ & 70 & 38 & $\ldots$ & $\ldots$ & 126 \\
\hline Subsidies & 5.3 & 12 & $\ldots$ & 17 & 12 & $\ldots$ & $\ldots$ & 47 \\
\hline Transfers & 0 & 0 & $\ldots$ & 12 & 8 & $\ldots$ & $\ldots$ & 36 \\
\hline Capital expenditure and net lending 4/ & 9 & 17 & $\ldots$ & 33 & 23 & $\ldots$ & $\ldots$ & 67 \\
\hline Overall balance (cash basis) & 266 & 424 & $\cdots$ & 872 & 587 & 1,038 & 1,508 & 1,667 \\
\hline Non-oil balance (cash basis) & 1 & -58 & $\cdots$ & -121 & -85 & -321 & -466 & -307 \\
\hline \multicolumn{9}{|l|}{ Financing } \\
\hline Changes in cash balances (increase = '-') & -266 & -424 & $\ldots$ & -872 & -587 & $-1,038$ & $-1,508$ & $-1,667$ \\
\hline & \multicolumn{8}{|c|}{ (In percent of non-oil GDP) } \\
\hline Revenue & 105 & 157 & 203 & 289 & 350 & 291 & 423 & 424 \\
\hline Domestic revenues & 12 & 10 & 11 & 11 & 10 & 4 & 6 & 7 \\
\hline Oil/gas revenues $2 /$ & 83 & 146 & 189 & 275 & 340 & 287 & 417 & 417 \\
\hline Grants & 11 & 0 & 3 & 3 & 0 & 0 & 0 & 0 \\
\hline Expenditure (commitment basis) $3 /$ & 23 & 36 & 86 & 71 & 52 & 72 & 105 & 86 \\
\hline Recurrent expenditure & 19 & 23 & 48 & 44 & 44 & 53 & 76 & 66 \\
\hline Capital expenditure and net lending $4 /$ & 4 & 13 & 38 & 27 & 8 & 19 & 29 & 21 \\
\hline Overall balance (commitment basis) $3 /$ & 82 & 121 & 117 & 218 & 298 & 219 & 319 & 337 \\
\hline Expenditure (cash basis) 5/ & 22 & 28 & $\ldots$ & 48 & 53 & $\ldots$ & $\ldots$ & 71 \\
\hline Recurrent expenditure & 19 & 23 & $\ldots$ & 39 & 41 & $\ldots$ & $\ldots$ & 57 \\
\hline Wages and salaries & 8 & 8 & $\ldots$ & 11 & 12 & $\ldots$ & $\ldots$ & 13 \\
\hline Goods and services & 10 & 12 & $\ldots$ & 19 & 19 & $\ldots$ & $\ldots$ & 27 \\
\hline Capital expenditure and net lending 4/ & 3 & 5 & $\ldots$ & 9 & 12 & $\ldots$ & $\ldots$ & 14 \\
\hline Overall balance (cash basis) & 83 & 129 & $\cdots$ & 242 & 297 & $\cdots$ & $\cdots$ & 352 \\
\hline Non-oil balance (cash basis) & 0 & -18 & $\ldots$ & -33 & -43 & $\ldots$ & $\ldots$ & -65 \\
\hline \multicolumn{9}{|l|}{ Financing } \\
\hline Changes in cash balances (increase = '-') & -83 & -129 & $\ldots$ & -242 & -297 & $\ldots$ & $\ldots$ & -352 \\
\hline \multicolumn{9}{|c|}{ Memorandum items (in percent of non-oil GDP, unless otherwise indicated): } \\
\hline Cash spending from past budgets $5 /$ & 4 & 3 & $\ldots$ & 5 & 22 & $\ldots$ & $\ldots$ & 10 \\
\hline Non-oil fiscal balance (commitment basis) & -1 & -26 & -72 & -57 & -42 & -68 & -98 & -80 \\
\hline Petroleum Fund balance (end-period) & $\ldots$ & 197 & 290 & 386 & 527 & 658 & $\ldots$ & 810 \\
\hline Sustainable spending $6 /$ & $\ldots$ & $\ldots$ & 92 & $\ldots$ & $\ldots$ & 66 & 90 & 90 \\
\hline Public debt & 0 & 0 & 0 & 0 & 0 & 0 & 0 & 0 \\
\hline
\end{tabular}

Sources: Timor-Leste authorities; and Fund staff estimates.

1/ Fiscal year: July-June until 2008, then calendar year. Central Government includes subsidies to Autonomous Agencies. 2/ Oil revenue projections are based on current budget assumptions for price and production.

3/ Staff projections are based on past ratios of actual commitments and cash disbursements to budgeted allocations. 4/ Includes allocations for BPA capitalization ( $\$ 10.5$ million in 2005/06).

5 / Cash expenditure includes carry-over expenditure from previous years (the reporting of which is not disaggregated). The carry-over is reportedly largely capital expenditure, as most recurrent expenditure is executed in the budgeted year. 6/ Permanent income from oil (estimated in line with the Petroleum Fund law) and projected domestic revenue and grants. 7/ Preliminary mid-year budget update, as of mid-May, 2007. 
Table 4. Timor-Leste: SIPs Combined Sources Budget, FY 2004/05-2008

\begin{tabular}{|c|c|c|c|c|c|}
\hline & $\begin{array}{r}2004 / 05 \\
\text { Est. }\end{array}$ & $\begin{array}{r}2005 / 6 \\
\text { Est. }\end{array}$ & $\begin{array}{r}2006 / 07 \\
\text { Est. }\end{array}$ & $\begin{array}{r}2007 \mathrm{H} 2 \\
\text { Est. }\end{array}$ & $\begin{array}{l}2008 \\
\text { Proj. }\end{array}$ \\
\hline & \multicolumn{5}{|c|}{ (In millions of U.S. dollars) } \\
\hline Revenue & 79 & 42 & 59 & 23 & 38 \\
\hline Domestic revenue $1 /$ & 37 & 34 & 40 & 20 & 31 \\
\hline Direct taxes & 11 & 9 & 12 & 7 & 11 \\
\hline Indirect taxes & 19 & 16 & 19 & 8 & 9 \\
\hline Nontax revenues and other & 7 & 9 & 9 & 6 & 12 \\
\hline Autonomous agencies own revenue & 8 & 7 & 7 & 3 & 7 \\
\hline Grant financing (budget support) & 34 & 1 & 11 & 0 & 0 \\
\hline Expenditure (cash basis) & 214 & 211 & 300 & 175 & 480 \\
\hline Recurrent expenditure & 162 & 154 & 229 & 131 & 371 \\
\hline Central government budget (incl. autonomous agencies) & 68 & 76 & 145 & 85 & 277 \\
\hline Donor projects $2 /$ & 93 & 78 & 84 & 47 & 94 \\
\hline Capital expenditure & 52 & 57 & 71 & 43 & 109 \\
\hline Central government budget (incl. autonomous agencies) & 10 & 13 & 35 & 23 & 68 \\
\hline Donor projects $2 /$ & 42 & 44 & 36 & 20 & 40 \\
\hline Overall balance & -134 & -169 & -242 & -151 & -442 \\
\hline Financing & 134 & 169 & 242 & 151 & 442 \\
\hline Oil fund financing of central government non-oil fiscal deficit 3 / & 209 & 0 & 260 & 40 & 227 \\
\hline Committed project financing by donors & 136 & 122 & 120 & 67 & 135 \\
\hline Change in cash balances (increase -) & -211 & 47 & -138 & 45 & 80 \\
\hline \multirow[t]{2}{*}{ Outstanding financing requests 4 / } & 0 & 0 & 0 & 0 & 0 \\
\hline & \multicolumn{5}{|c|}{ (In percent of non-oil GDP) } \\
\hline Revenue & 25 & 13 & 16 & 12 & 8 \\
\hline Domestic revenue $1 /$ & 12 & 10 & 11 & 10 & 7 \\
\hline Autonomous agencies own revenue & 3 & 2 & 2 & 2 & 2 \\
\hline Grant financing (budget support) & 11 & 0 & 3 & 0 & 0 \\
\hline Expenditure (cash basis) 2/ & 67 & 64 & 83 & 88 & 101 \\
\hline Recurrent expenditure & 50 & 47 & 64 & 66 & 78 \\
\hline Capital expenditure & 16 & 17 & 20 & 22 & 23 \\
\hline Overall Balance & -42 & -51 & -67 & -77 & -93 \\
\hline Financing & 42 & 51 & 67 & 77 & 93 \\
\hline Oil fund financing of non-oil fiscal deficit $3 /$ & 65 & 0 & 72 & 20 & 48 \\
\hline Committed project financing by donors & 42 & 37 & 33 & 34 & 28 \\
\hline Change in cash balances (increase -) & -66 & 14 & -38 & 23 & 17 \\
\hline Outstanding financing requests 4 / & 0 & 0 & 0 & 0 & 0 \\
\hline Memorandum items: & \multicolumn{5}{|c|}{ (In millions of U.S. dollars, unless otherwise specified) } \\
\hline Non-oil fiscal balance & 1 & -47 & -121 & -85 & -307 \\
\hline Oil/Gas revenue & 266 & 482 & 993 & 672 & 1974 \\
\hline Oil fund balance (in percent of non-oil GDP) & 22 & 197 & 386 & 527 & 810 \\
\hline Total donor financing requested & 136 & 122 & 120 & 67 & 135 \\
\hline Committed & 136 & 122 & 120 & 67 & 135 \\
\hline Uncommitted & 1 & 0 & 0 & 0 & 0 \\
\hline
\end{tabular}

Sources: Timor-Leste authorities; and Fund staff estimates.

1/ Oil gas revenue are not included as a budget revenue item and flows directly to the petroleum fund. The amount necessary to cover the non-oil fiscal deficit is withdrawn from the fund transferred to the budget up to the estimated sustainable income level and recorded as a financing item.

2/ Includes sector projects which the government has identified as necessary to achieve NDP objectives, but may not be wholly funded. $3 / \mathrm{Oil} / \mathrm{gas}$ revenue is included in the line of oil fund financing.

4/ New projects financing requested from donors; still uncommitted. 
Table 5. Timor-Leste: Balance of Payments, 2003-08

\begin{tabular}{|c|c|c|c|c|c|c|}
\hline & 2003 & 2004 & 2005 & 2006 & 2007 & 2008 \\
\hline & \multicolumn{5}{|c|}{ Estimates } & Proj. \\
\hline & \multicolumn{6}{|c|}{ (In millions of U.S. dollars) } \\
\hline Current account excl. international assistance & -479 & -321 & 34 & 295 & 771 & 1,333 \\
\hline Current account incl. international assistance & -23 & 26 & 273 & 531 & 1,168 & 1,689 \\
\hline Trade balance & -121 & -121 & -117 & -114 & -192 & -299 \\
\hline Exports of goods $1 /$ & 8 & 8 & 9 & 9 & 8 & 11 \\
\hline O/w: coffee & 7 & 7 & 8 & 8 & 7 & 9 \\
\hline Imports of goods & -130 & -129 & -125 & -123 & -200 & -309 \\
\hline Services (net) & -330 & -302 & -159 & -183 & -324 & -316 \\
\hline Income (net) & 20 & 149 & 365 & 647 & 1,330 & 1,991 \\
\hline O/w: oil/gas revenue and interest & 13 & 141 & 354 & 637 & 1,312 & 1,974 \\
\hline Current transfers (net) & 408 & 300 & 185 & 181 & 354 & 312 \\
\hline O/w: international assistance & 408 & 299 & 184 & 180 & 354 & 312 \\
\hline Capital and financial accounts & 41 & 95 & -303 & -600 & $-1,021$ & $-1,689$ \\
\hline Official capital transfers & 47 & 47 & 55 & 56 & 42 & 44 \\
\hline Financial account & -6 & 47 & -357 & -656 & $-1,063$ & $-1,733$ \\
\hline O/w: oil/gas savings & -3 & -3 & -358 & -637 & $-1,012$ & $-1,747$ \\
\hline Overall balance & 18 & 121 & -29 & -70 & 147 & 0 \\
\hline \multirow[t]{2}{*}{ Changes in foreign assets (increase -) } & -18 & -121 & 29 & 70 & -147 & 0 \\
\hline & \multicolumn{6}{|c|}{ (In percent of non-oil GDP) } \\
\hline Current account excl. international assistance & -161 & -104 & 10 & 90 & 195 & 282 \\
\hline Current account incl. international assistance & -8 & 9 & 82 & 162 & 295 & 357 \\
\hline Current account excl. oil and gas revenue & -12 & -37 & -24 & -32 & -37 & -60 \\
\hline Trade balance & -41 & -39 & -35 & -35 & -49 & -63 \\
\hline & \multicolumn{6}{|c|}{ (In millions of U.S. dollars) } \\
\hline \multicolumn{7}{|l|}{ Memorandum item: } \\
\hline Public foreign assets (end-period) & 72 & 196 & 524 & 1,096 & 2,316 & 4,064 \\
\hline
\end{tabular}


Table 6. Timor-Leste: Monetary Developments, 2002-08

\begin{tabular}{|c|c|c|c|c|c|c|c|}
\hline & 2002 & 2003 & 2004 & 2005 & 2006 & 2007 & $\begin{array}{r}2008 \\
\text { proj. }\end{array}$ \\
\hline & \multicolumn{7}{|c|}{ (In millions of U.S. dollars) } \\
\hline \multicolumn{8}{|l|}{ Banking System } \\
\hline Net foreign assets & 70 & 108 & 184 & 159 & 113 & 318 & 305 \\
\hline Assets 1/ & 75 & 142 & 227 & 206 & 144 & 356 & 351 \\
\hline Gross reserves & 43 & 61 & 182 & 153 & 84 & 230 & 160 \\
\hline Liabilities & 5 & 34 & 43 & 47 & 31 & 38 & 46 \\
\hline Net domestic assets & -25 & -45 & -116 & -80 & -11 & -172 & -114 \\
\hline Claims on government (net) & -45 & -61 & -187 & -151 & -83 & -219 & -140 \\
\hline Claims on private sector & 6 & 26 & 88 & 106 & 111 & 101 & 106 \\
\hline Other ("net other assets") & 0 & 0 & 0 & 0 & 0 & 0 & 0 \\
\hline Other items, net (inc capital account) & 14 & -10 & -18 & -35 & -40 & -54 & -79 \\
\hline Broad money 2 I & 44 & 62 & 66 & 78 & 100 & 144 & 187 \\
\hline Narrow money & 38 & 33 & 32 & 39 & 54 & 75 & 97 \\
\hline Currency in circulation & 0 & 1 & 1 & 2 & 2 & 2 & 2 \\
\hline Demand deposits & 38 & 32 & 31 & 38 & 52 & 73 & 95 \\
\hline Other deposits & 6 & 29 & 34 & 38 & 46 & 68 & 90 \\
\hline Non-liquid liabilities & 2 & 1 & 2 & 1 & 2 & 2 & 4 \\
\hline \multicolumn{8}{|l|}{ Banking and Payments Authority (central bank) } \\
\hline Net foreign assets $1 /$ & 44 & 61 & 182 & 153 & 84 & 230 & 160 \\
\hline Assets & 44 & 61 & 182 & 153 & 84 & 230 & 160 \\
\hline Gross reserves & 43 & 61 & 182 & 153 & 84 & 230 & 160 \\
\hline Others & 0 & 0 & 0 & 0 & 0 & 0 & 0 \\
\hline Liabilities & 0 & 0 & 0 & 0 & 0 & 0 & 0 \\
\hline Net domestic assets $3 /$ & -38 & -54 & -175 & -147 & -74 & -210 & -128 \\
\hline Central Government (net position) & -34 & -50 & -169 & -129 & -56 & -190 & -110 \\
\hline Claims on domestic banks and other claims & -4 & -4 & -7 & -18 & -18 & -19 & -19 \\
\hline Other Items, net & 1 & 1 & 1 & 1 & 1 & 1 & 1 \\
\hline Liabilities & 6 & 7 & 7 & 6 & 9 & 21 & 32 \\
\hline Currency in circulation 2/ & 0 & 1 & 1 & 2 & 2 & 2 & 2 \\
\hline Financial institutions & 4 & 6 & 5 & 5 & 6 & 18 & 29 \\
\hline Other deposits and liquid liabilities & 0 & 0 & 0 & 0 & 0 & 0 & 0 \\
\hline Non-liquid liabilities & 1 & 0 & 1 & 0 & 1 & 0 & 0 \\
\hline \multicolumn{8}{|l|}{ Commercial banks 4 I } \\
\hline Net foreign assets & 27 & 47 & 1 & 6 & 29 & 88 & 145 \\
\hline Assets & 31 & 80 & 44 & 52 & 61 & 126 & 191 \\
\hline Liabilities & 5 & 34 & 43 & 47 & 31 & 38 & 46 \\
\hline Net domestic assets & 18 & 15 & 65 & 71 & 70 & 55 & 43 \\
\hline Deposits with BPA & 2 & 7 & 5 & 3 & 5 & 16 & 27 \\
\hline Claims on government (net) & -11 & -11 & -18 & -23 & -27 & -28 & -30 \\
\hline Claims on private sector & 6 & 26 & 88 & 106 & 111 & 100 & 106 \\
\hline Other ("net other assets") & 0 & 0 & 0 & 0 & 0 & 0 & 0 \\
\hline Other items (net) & 22 & 2 & 4 & 1 & -43 & -52 & -59 \\
\hline Deposit liabilities & 44 & 62 & 66 & 77 & 99 & 143 & 188 \\
\hline Demand deposits & 38 & 32 & 31 & 38 & 52 & 73 & 95 \\
\hline Time and Savings Deposits & 6 & 29 & 34 & 38 & 46 & 68 & 90 \\
\hline Deposits Excluded from Broad Money & 0 & 1 & 1 & 1 & 1 & 2 & 3 \\
\hline \multicolumn{8}{|l|}{ Memorandum items } \\
\hline Petroleum Fund balance (millions) $1 /$ & $\ldots$ & & & 370 & 1,012 & 2,086 & 3,834 \\
\hline Net foreign assets (annual percentage change) & $\ldots$ & 54.0 & 70.0 & -13.4 & -28.8 & 181.1 & -4.2 \\
\hline Credit to the private sector (annual percentage change) & & 309.9 & 237.2 & 19.8 & 5.2 & -9.8 & 5.0 \\
\hline Credit/non-oil GDP (percent) & 2.2 & 8.9 & 28.6 & 31.9 & 34.1 & 25.4 & 22.3 \\
\hline Deposits/non-oil GDP ratio (percent) & 15.4 & 20.7 & 21.3 & 23.5 & 30.6 & 36.3 & 39.5 \\
\hline Credit to deposits ratio (percent) & 14.5 & 42.2 & 133.9 & 137.4 & 112.5 & 70.1 & 56.1 \\
\hline
\end{tabular}

Sources: Banking and Payments Authority; and Fund staff estimates.

1/ An oil fund was created in September 2005 and the deposits were moved off-shore and onto the Government balance sheet. 2/ Includes only coinage issued by the BPA as no data is available for notes due to dollarization of the financial system.

3/ The large decrease in 2004 reflects the build up of oil-related government deposits.

4/ Includes three commercial banks (branches of foreign banks) and a micro-finance institution. 
Table 7. Timor-Leste: Medium-Term Outlook, 2006-13 (Baseline Scenario)

\begin{tabular}{|c|c|c|c|c|c|c|c|c|}
\hline & 2006 & 2007 & 2008 & 2009 & 2010 & 2011 & 2012 & 2013 \\
\hline & \multicolumn{7}{|c|}{ Staff Projections } & \\
\hline \multicolumn{9}{|l|}{ Output and prices } \\
\hline GNI at current prices (in millions of US dollars) & 974 & 1,725 & 2,464 & 2,178 & 2,357 & 2,388 & 2,234 & 2,274 \\
\hline Of which: Non-oil GDP & 327 & 396 & 473 & 530 & 584 & 635 & 684 & 738 \\
\hline Oil/gas income & 637 & 1,309 & 1,974 & 1,632 & 1,757 & 1,738 & 1,535 & 1521 \\
\hline Real non-oil GDP growth (percentage change) & -5.8 & 7.8 & 6.8 & 5.9 & 5.7 & 4.6 & 4.5 & 4.5 \\
\hline Including United Nations $1 /$ & -3.4 & 16.2 & 4.7 & 2.2 & 2.1 & 2.0 & 3.2 & 4.1 \\
\hline Inflation (percentage change, period average) & 4.1 & 8.9 & 9.0 & 7.0 & 6.0 & 5.0 & 3.5 & 3.5 \\
\hline & \multicolumn{8}{|c|}{ (In percent of non-oil GDP) } \\
\hline \multicolumn{9}{|l|}{ Investment-saving balance } \\
\hline Gross investment 2/ & 21 & 28 & 31 & 36 & 40 & 40 & 40 & 40 \\
\hline Gross national saving & 183 & 323 & 387 & 263 & 258 & 234 & 188 & 173 \\
\hline External saving & -162 & -295 & -357 & -227 & -218 & -194 & -148 & -133 \\
\hline \multicolumn{9}{|l|}{ Central government budget $3 /$} \\
\hline Revenues & 289 & 350 & 424 & 313 & 306 & 280 & 231 & 213 \\
\hline Domestic revenue & 11 & 10 & 7 & 5 & 5 & 6 & 6 & 7 \\
\hline Oil/gas revenue & 275 & 340 & 417 & 308 & 301 & 274 & 224 & 206 \\
\hline Grants & 3 & 0 & 0 & 0 & 0 & 0 & 0 & 0 \\
\hline Expenditure & 48 & 53 & 71 & 73 & 76 & 74 & 72 & 69 \\
\hline Recurrent expenditure & 39 & 41 & 57 & 54 & 52 & 50 & 48 & 46 \\
\hline Capital expenditure & 9 & 12 & 14 & 20 & 24 & 24 & 24 & 23 \\
\hline Overall balance & 242 & 297 & 352 & 240 & 230 & 206 & 159 & 144 \\
\hline Non-oil fiscal balance & -33 & -43 & -65 & -69 & -71 & -68 & -65 & -62 \\
\hline Public debt & 0 & 0 & 0 & 0 & 0 & 0 & 0 & 0 \\
\hline Oil/gas savings (stock) & 310 & 527 & 810 & 963 & 1,103 & 1,221 & 1,292 & 1,342 \\
\hline \multicolumn{9}{|l|}{ Combined sources fiscal operations 4/ } \\
\hline Revenues & 16 & 12 & 8 & 7 & 7 & 8 & 9 & 9 \\
\hline Expenditure & 83 & 88 & 101 & 100 & 98 & 92 & 88 & 84 \\
\hline Overall balance & -67 & -77 & -93 & -94 & -91 & -85 & -79 & -75 \\
\hline Financing & 122 & 32 & 83 & 79 & 75 & 68 & 63 & 60 \\
\hline Net transfers from oil fund & 131 & 8 & 43 & 62 & 65 & 63 & 60 & 58 \\
\hline Committed financing by donors & 61 & 14 & 25 & 16 & 10 & 5 & 3 & 2 \\
\hline Outstanding financing requests & 0 & 0 & 0 & -6 & -9 & -10 & -11 & -10 \\
\hline & \multicolumn{8}{|c|}{ (In millions of U.S. dollars) } \\
\hline \multicolumn{9}{|l|}{ External sector } \\
\hline Current account balance & 531 & 1,168 & 1,689 & 1,202 & 1,275 & 1,229 & 1,015 & 981 \\
\hline Trade balance & -114 & -192 & -299 & -416 & -458 & -476 & -486 & -506 \\
\hline Merchandise exports 5/ & 9 & 8 & 11 & 12 & 13 & 14 & 15 & 16 \\
\hline Merchandise imports & -123 & -200 & -309 & -428 & -471 & -490 & -501 & -523 \\
\hline Oil income & 637 & 1,312 & 1,974 & 1,632 & 1,757 & 1,738 & 1,535 & 1521 \\
\hline Overall balance & -70 & 147 & 0 & 0 & 0 & 0 & 0 & 0 \\
\hline Public foreign assets (end-period) & 1,096 & 2,316 & 4,064 & 5,333 & 6,676 & 7,981 & 9,070 & 10133 \\
\hline (in months of imports of goods and services) & 107 & 139 & 158 & 150 & 170 & 196 & 217 & 233 \\
\hline & \multicolumn{8}{|c|}{ (In percent of non-oil GDP) } \\
\hline Current account excl. international assistance & 90 & 195 & 282 & 172 & 183 & 170 & 131 & 118 \\
\hline Current account incl. international assistance & 162 & 295 & 357 & 227 & 218 & 194 & 148 & 133 \\
\hline Overall balance & -21 & 37 & 0 & 0 & 0 & 0 & 0 & 0 \\
\hline
\end{tabular}

Sources: Data provided by the Timor-Leste authorities; and Fund staff estimates and projections.

$1 /$ Includes locally paid compensation of UN peacekeeping mission staff.

2/ Excludes oil/gas sector investment.

3/ Fiscal year (July-June) up FY2006/07 (in column for 2006); 2007H2 in column for 2007; calendar years subsequently. 4/ On a fiscal year basis. Includes autonomous agencies and fiscal and quasi-fiscal expenditure programs undertaken by bilateral donors and international financial institutions outside the central government budget.

5/ Excludes oil/gas revenue, which is recorded under the income account. 


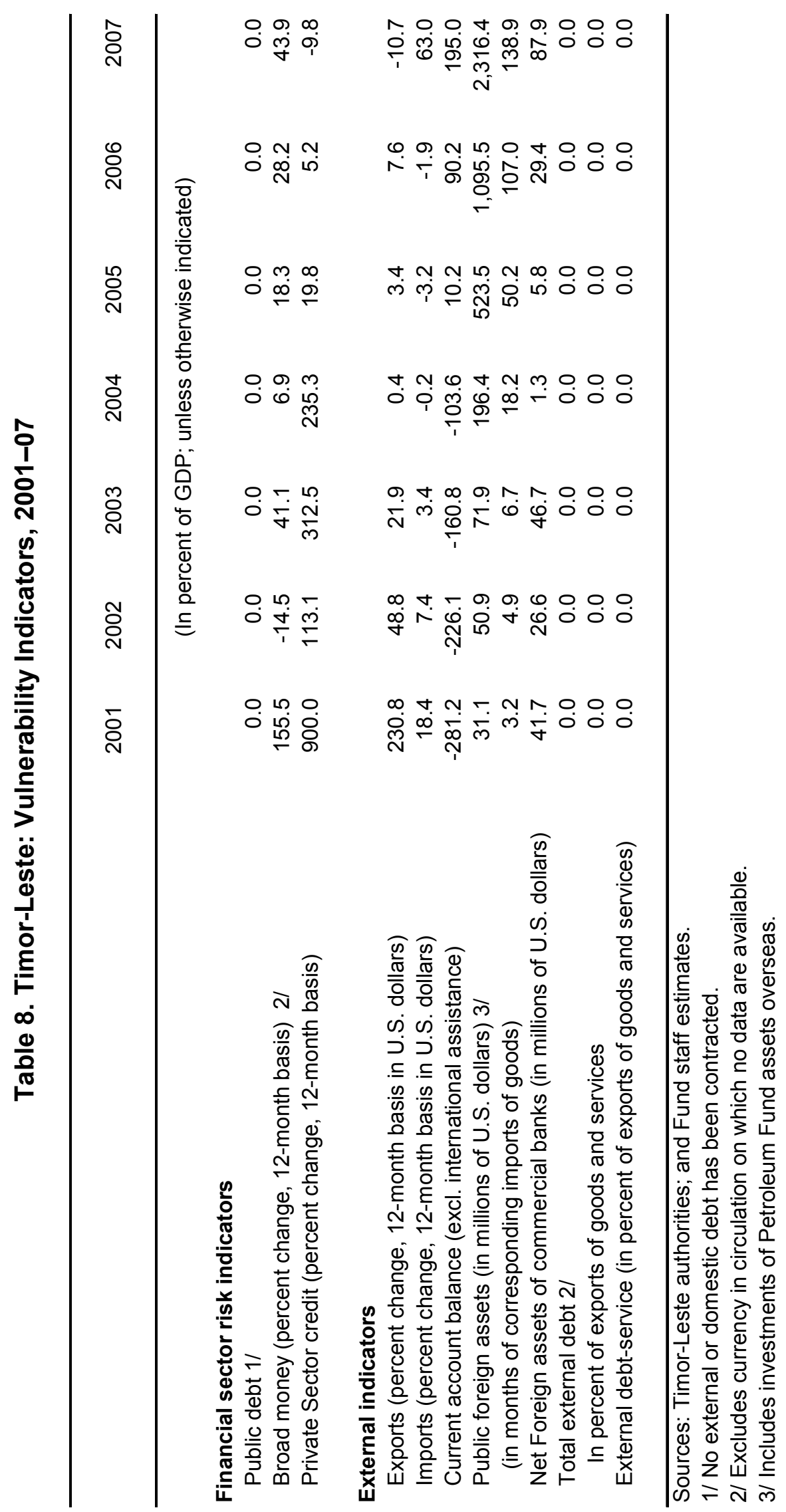




\section{INTERNATIONAL MONETARY FUND \\ DEMOCRATIC REPUBLIC OF TIMOR-LESTE \\ Staff Report for the 2008 Article IV Consultation-Informational Annex}

Prepared by the Asia and Pacific Department

June 10, 2008

Contents

Page

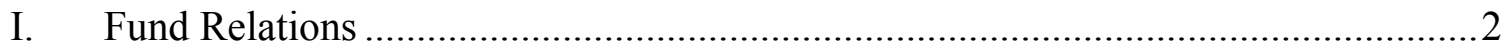

II. Relations with the World Bank Group.......................................................

III. Relations with the Asian Development Bank ..................................................

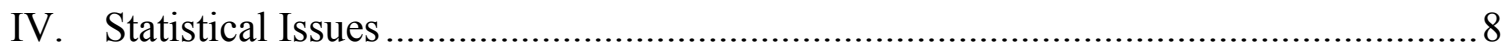




\section{ANNEX I. TIMOR-LeSTE: FUnd RELATIONS}

(As of April 30, 2008)

I. Membership Status: Joined 7/23/2002; Article VIII

II. General Resources Account:

SDR Million $\quad \%$ Quota

Quota

100.00

Fund holdings of currency

8.20

100.00

Reserve position in Fund

0.00

0.01

\section{SDR Department:}

Net cumulative allocation None

Holdings None

IV. Outstanding Purchases and Loans: None

V. Financial Arrangements: None

VI. Projected Obligations to Fund: None

\section{Exchange Rate Arrangements}

On January 24, 2000, the U.S. dollar was adopted as the official currency of then East Timor by the United Nations Transitional Administration in East Timor (UNTAET). This arrangement has been maintained after Timor-Leste's independence on May 20, 2002. At present, the monetary authority does not undertake foreign exchange transactions; they are handled by commercial banks on the basis of rates quoted in the international markets.

\section{Article IV Consultations}

The 2006 Article IV consultation discussions with the authorities were held during October 9-20, 2006. The last Article IV consultation was concluded on January 29, 2007. The Public Information Note may be found at http://www.imf.org/external/np/sec/pn/2007/pn0724.htm.

\section{Technical Assistance}

Since late 1999, a significant amount of technical assistance has been provided by the Fund as part of the international community's efforts to reconstruct the Timor-Leste economy. The Fund's technical assistance has 
focused on establishing key economic institutions (especially fiscal and monetary authorities) essential for macroeconomic management, as well as on developing local capacity to manage them. It also played a key role in the adoption of a new currency arrangement based on the U.S. dollar. Between late 1999 and end-2007, Timor-Leste has been one of the largest recipients of Fund technical assistance.

FAD: A series of multi-topic FAD missions took place early on to establish and develop the Central Fiscal Authority (CFA, February 2000), which developed into the Ministry of Planning and Finance. Assistance was provided to develop budget preparation, establish tax policy and administration, strengthen treasury and expenditure management, and advise on oil sector fiscal regimes. Long-term resident advisors were assigned to the Ministry of Planning and Finance and the Revenue Service of Timor-Leste to cover a wide range of issues, partly under a cost sharing arrangement with the UN. Over August 2004-July 2005, a FAD resident advisor assisted in the design and establishment of the Petroleum Fund, which started operations in August 2005. A FAD resident advisor to the Treasurer of the ministry finance started work in December 2006 to help strengthen expenditure management, reporting and budget execution — after a short break, a replacement will commence in June 2008 to continue this work. In 2007, an FAD TA mission provided guidance for future reform of the non-oil tax regime.

LEG: A number of LEG missions have been to Timor Leste to advise the authorities on key fiscal and financial legislation. These included tax legislation, the budget and financial management law, and banking regulations (relating to the monetary authority, the banking system, and the payments system). Jointly with MFD (now MCM), technical assistance has been provided to assist in drafting an AML/CFT Law. LEG has also recently provided assistance, in collaboration with FAD, for the drafting of the Petroleum Fund Act and tax consolidation, and in collaboration with MCM, for the drafting of the Central Bank Law.

MCM: A large number of missions took place early on to establish and develop the Central Payments Office (CPO, January 2000), which was transformed subsequently into the Banking and Payments Authority (BPA) (November 2001). Assistance was provided to establish a payment system, prepare banking legislation, and develop key functions of the monetary authority, including banking supervision, asset management, accounting, and organization and management. Assistance was also provided on the introduction of a dollar-based currency system and to issue domestic coins to supplement the use of U.S. dollar coins. More recently, assistance has been provided to (i) draft the insurance law and develop a framework for insurance supervision, (ii) strengthen banking supervision, (iii) address a broad range of issues relating to money laundering and 
financing of terrorism, (iv) establish and train the investment unit responsible for managing petroleum fund assets (funded by Norway, a resident adviser commenced in March 2005 and, after a break due to contract renegotiations, a replacement is expected to commence in 2008), (v) prepare for the establishment of the central bank, (vi) design of a more effective organizational structure at the BPA, and (vii) modernize payment systems, and accounting for the Petroleum Fund. In addition, long-term resident advisors, including on banking supervision, payments, and accounting, have been assigned to the BPA under a cost sharing arrangement with the UN. Since early 2005, a long-term advisor has been assisting the BPA general manager.

STA: A multi-sector statistical mission took place in November 2000 to assess the availability and quality of official macroeconomic data, and help establish the Statistic Division of the Ministry of Planning and Finance. A long term statistical advisors was provided over the period November 2001-October 2005. A peripatetic statistical advisor was appointed in 2007 and is assisting the authorities in improving data compilation and developing local capacity to prepare balance of payments statistics - responsibility for this was transferred to the BPA in 2007. In early 2008 a monetary and financial statistics mission helped introduce the standardized report forms (SRFs) for reporting monetary data to the IMF and an integrated monetary database. Subsequently, Timor-Leste has, for the first time, been able to publish a country page in IFS.

\section{Resident Representative}

A resident representative office was established in Dili in August 2000. The current resident representative, Mr. Tobias Rasmussen assumed the post in February 2006. 


\section{ANNEX II. TIMOR-LESTE: RELATIONS WITH THE WORLD BANK GROUP}

(As of May 6, 2008)

1. Timor-Leste joined the World Bank Group on July 23, 2002. It became eligible for IDA assistance on October 9, 2002. Thus far, there has been no lending to Timor-Leste, reflecting the authorities' policy to avoid external borrowing, including concessional loans. However, the World Bank has been actively involved in the reconstruction and development of the economy since late 1999 , by playing a key catalytic role in mobilizing and coordinating international assistance to Timor-Leste. Timor-Leste also joined IFC in September 2004 and, together with the Pacific Enterprise Development Facility, an office was opened in Dili in 2006.

2. During the transition to independence, the World Bank's involvement centered around its role as trustee and co-manager of the Trust Fund for East Timor (TFET), which was established in December 1999 as a vehicle to provide grant assistance for reconstruction activities and economic development in Timor-Leste. Under the TFET, which is co-managed with the Asian Development Bank (ADB), the World Bank has administered projects relating to social services (especially health and education), agriculture, private sector development, community development and governance, economic capacity building, and petroleum sector development. ${ }^{1}$

3. In addition to its involvement through the TFET, the World Bank played a key role in mobilizing budgetary assistance for the post-independence period through an annual multidonor budget support operation. The Transition Support Program (TSP) from FY 2003 to 2005, was followed by the Consolidation Support Program (CSP) to FY2006/07, to reflect the shift from post-conflict transition to consolidation of gains made thus far. The TSP programs brought about $\$ 30$ million in budget support annually with about $\$ 5$ million financed by IDA, and the balance financed by 9 bilateral partners. The CSP programs brought around $\$ 10$ million in budget support annually, with about $\$ 0.5$ million financed by IDA. Both the TSP and the CSP programs focused on three thematic areas: (1) good governance, including developing a legal framework for governance and the judiciary and strengthening public expenditure management; (2) service delivery for poverty reduction, particularly in education and health; and (3) job creation, especially through private sector development, agriculture, and improvements in basic infrastructure.

4. The World Bank has also provided analytical and advisory services, including through a Country Economic Memorandum, a Poverty Assessment, a Public Expenditure Management and Accountability Note, a Public Expenditure Review, an Education Sector Review, and a Paper on Strengthening the Institutions of Governance in Timor-Leste. The

\footnotetext{
${ }^{1}$ Pledges to the TFET were made by 12 donors, including the European Commission and the World Bank, with the total amount of funds reaching $\$ 178$ million. This comprises donors' contributions of $\$ 167$ million (including \$10 million by the World Bank) and investment income of \$9 million. Of this total, \$167 million was disbursed by end-February 2008 (a new Trustee Report is now under preparation and should be released before end-May). TFET projects are expected to wind down by end-2010.
} 
"Doing Business" report for 2006 featured Timor-Leste for the first time and was updated for 2007.

5. In July 2005 the World Bank adopted a Country Assistance Strategy for FY 2006-08. Currently the World Bank Group, including the International Finance Corporation (IFC), is supporting and planning to support 21 projects covering the development of the power sector; the health care system; developing the education sector; the development of private business and agriculture; transparency in the management of petroleum resources; supporting war veterans; promoting leadership and communication, a national employment program and a comprehensive framework for youth policy. The CAS provided for a total amount of IDA grants of about US\$ 25 million. One of the largest overall programs is a Planning and Financial Management Capacity Building Project, approved in March 2006, that amounts to \$37 million with \$7 million from IDA and \$30 million from development partners.

6. As budget support is no longer required given the increase in petroleum revenue, the CSP program will be replaced by donor support for the Government's 2008 National Priorities. These include six priority areas where progress could lead to a transformation in the under-performing economy and improve significantly the lives of Timor-Leste's one million citizens. These six priorities are: i) transparent management of the country's petroleum resources; ii) budget execution; iii) addressing the youth crisis; iv) creating an environment for private investment; v) improving service delivery; and vi) protecting the most vulnerable

7. The World Bank used to co-chair the Timor-Leste Development Partners Meeting (TLDPM) with the Government of Timor-Leste. The seventh and latest TLDPM took place at the end of March 2008 and it was just chaired by the Government. The World Bank and UNMIT (UN Integrated Mission to Timor-Leste) helped the preparation of the government's background paper to the TLDPM. 


\section{ANNEX III. Timor-LeSTe: RELATIONS With THE ASIAN DEVELOPMENT BANK}

(As of May 2, 2008)

1. Timor-Leste joined the Asian Development Bank (AsDB) on July 24, 2002. To date, there has been no lending to the country. However, like other international financial institutions and bilateral donors, the AsDB has been actively involved in the reconstruction and development of the economy since late 1999.

2. The AsDB's involvement has centered around co-managing with the World Bank the Trust Fund for East Timor (TFET), which was established in December 1999 as a vehicle to provide grant assistance for reconstruction activities and economic development in TimorLeste. ${ }^{2}$ Under the TFET, the AsDB has managed six projects with total funding of $\$ 51.7$ million, ${ }^{3}$ which aimed at the rehabilitation of physical infrastructure (urban and rural power, national roads, ports, and water and sanitation) and the development of microfinance.

3. In the wake of the post-referendum destruction, the focus of the projects was on providing emergency assistance, but subsequently shifted to meeting the country's long-term development needs. The AsDB's Country Operations Business Plan 2008 to 2010 identifies infrastructure development and management as the primary focus of ADB support to TimorLeste. An ongoing road rehabilitation project (\$10 million grant) and Dili water supply project ( $\$ 6$ million grant) are funded through the $9^{\text {th }}$ Asian Development Fund (ADF IX). The recently negotiated ADF X allocates approximately $\$ 20$ million for the first biennial period 2009-2010, entirely on a grant basis. Most of this money will support road maintenance, rehabilitation, and improvement. Additional ADB technical assistance will average approximately $\$ 2$ million per annum. Allocations will be confirmed in a new Country Partnership Strategy for 2009-2013. Timor-Leste is the recipient of AsDB's largest ever technical assistance (TA) grant, the Infrastructure Project Management TA. This \$15 million 4 year package finances international and domestic project engineers, procurement specialists, and others to work within the Ministry of Infrastructure to help plan, prepare, and execute the Government's capital development program.

4. AsDB is currently preparing a private sector development support program, with a likely focus on access to finance (secured transactions) and public-private-partnerships in infrastructure development. AsDB has also intensified efforts to strengthen and divest the Microfinance Institute of Timor-Leste (IMfTL).

\footnotetext{
${ }^{2}$ See footnote 1 in Relations with the World Bank Group.

${ }^{3}$ These projects comprise the Emergency Infrastructure Rehabilitation Project (\$29.8 million); the Emergency Infrastructure Rehabilitation Project 2 (\$9 million); the Water Supply and Sanitation Rehabilitation Project ( $\$ 4.5$ million); the Water Supply and Sanitation Rehabilitation Project 2 (\$4.5 million); the Hera Fisheries Port Facilities Rehabilitation Project (\$1 million); and the Microfinance Development Project (originally $\$ 4$ million, but reduced to $\$ 2.7$ million)
} 


\section{AnNeX IV. Timor-Leste: StATISTICAL ISSUES}

Data provision to the Fund has serious shortcomings that significantly hamper surveillance. Weaknesses remain in the macroeconomic data, especially in the balance of payments and the national accounts. Prior to 1999, macroeconomic data were compiled by the Indonesian Central Bureau of Statistics (Badan Pusat Statistik, BPS) and the Central Board of Statistics of the East Timor Province. Balance of payments statistics were almost nonexistent as Timor-Leste was treated as one of the Indonesian provinces. Data compilation was seriously disrupted in 1999, as the post-referendum turmoil destroyed databases, and institutional capacity collapsed after most Indonesian statistical officers left.

During reconstruction, international financial institutions and bilateral donors provided technical assistance. A multi-sector Fund statistics mission visited Dili in November 2000 and assisted the authorities in establishing objectives for restoring economic statistics and in setting up a Statistical Division in the Ministry of Planning and Finance in 2001. A long-term resident statistical advisor assisted the Statistical Division during November 2001-February 2004, and was succeeded by a new resident advisor until September 2005.

\section{National accounts}

Under a World Bank-financed project, national accounts data for 2000 (both sector and expenditure basis) were estimated by the Boston Institute for Developing Economies (BIDE). In late 2004, BIDE, under a follow-up World Bank project, produced GDP estimates for 2001-03 that suffer from limited source data and substantial extrapolation. The Division of Statistics has not been able to replicate the BIDE estimation exercise. Consequently, estimates of GDP (including for the oil sector) have been prepared by Fund staff. To improve national accounts data, appropriate staff and substantial efforts in data collection and compilation are needed. The authorities have secured a commitment from the World Bank for further support on national accounts.

\section{Prices, employment, and wages}

A consumer price index has been compiled monthly for Dili and for the whole country. To address quality weaknesses, in particular inappropriate and outdated weights, the commodity basket and the weighting scheme were revised in mid-2003 under a donor-supported project, and a new monthly index for Dili has been compiled, with December 2001 as the base period. A further update of CPI weights based on detailed consumption patterns is not expected before 2009 as the authorities are focusing on the conduct of a World Bank living standards measurement survey. 
Annual data on public sector employment and wages are available through fiscal records. No official data are compiled regularly on private sector employment and wages, except for partial data from household surveys conducted jointly by UNDP, ADB, and the World Bank.

\section{Government financial statistics}

Official data on central government revenue and expenditure are published semi-annually. Audited annual financial statements of the executed budget are made available to APD as soon as they are released, normally three months after the end of the fiscal year. In addition, monthly data are available on request through the budget, treasury, and revenue services. The compilation of revenue and expenditure follows the classification of the Manual on Government Finance Statistics (GFSM 1986) (including expenditure based on both functional and economic classification). Data on the execution of expenditure carried over from past fiscal years are not yet compiled and reported regularly. Only partial data are available on fiscal and quasi-fiscal activities undertaken by bilateral donors outside the central government budget. Currently, there are four non-financial public enterprises, which are treated as government agencies and data on their operations are available in the audited annual financial statements. No data are currently reported for the GFS Yearbook and the International Financial Statistics.

\section{Monetary accounts}

Monetary statistics are compiled by the Banking and Payments Authority (BPA), generally following the methodology of the Monetary and Financial Statistics Manual. However, data are incomplete because of the absence of official data on public currency holdings - which are difficult to compile under the current currency regime - and of bank's positions with public nonfinancial corporations. The BPA publishes a quarterly bulletin and an annual report with key monetary aggregates.

Detailed monthly monetary data are now available from July 2002 onward following the introduction of the standardized report forms (SRFs). Beginning in February 2008, monetary data are reported to the IMF for publication in the International Financial Statistics and IFS Supplement on Monetary and Financial Statistics. SRF-based data will be used for the Fund's operational and publication purposes. The BPA is planning to introduce a new call report form in 2008 to obtain balance sheet information from other depository corporations. A follow-up mission has been tentatively scheduled during FY09 to assist the authorities in this endeavor. 


\section{Balance of payments}

No official data are available, except on merchandise exports and imports (starting March 2000), but no reports are available since July 2007. There are significant gaps in these series, which are based on customs reports with a breakdown for major commodity categories. However, data do not include oil and gas exports. Trade data do not include any estimate of large unrecorded border trade. In the Fund staff estimates, data on oil/gas revenue are currently recorded as current income based on fiscal data. All other major items in the balance of payments are estimated by Fund staff on the basis of limited information obtained from various sources, including bilateral donors and banks. To address institutional weaknesses in the compilation of the balance of payments, the Ministry of Finance transferred responsibility for the compilation of the balance of payments to the BPA in 2007. An STA peripatetic advisor is currently assisting the BPA to develop balance of payments statistics. 
11
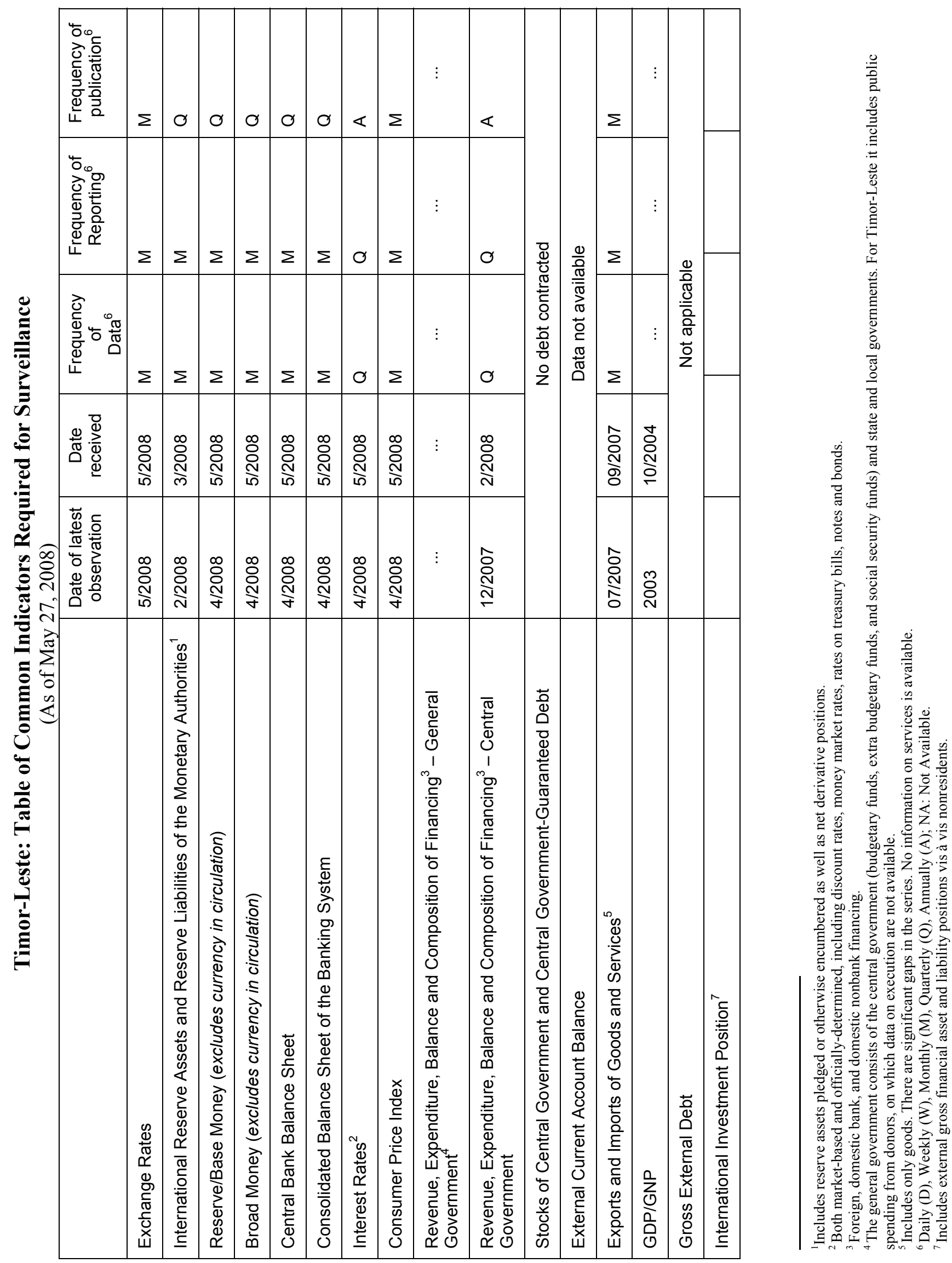


\section{Statement by the IMF Staff Representative \\ June 25, 2008}

1. This statement provides information that has become available since the circulation of the staff report. The new information does not alter the thrust of the staff appraisal.

2. The 2008 mid-year budget update (MYBU) was approved by the Council of Ministers on June 18 and will shortly be sent to Parliament for consideration. Revenue estimates are expected to be close to staff's projections of 424 percent of non-oil GDP. However, there is a sharp increase in spending appropriations relative to the figures discussed during the consultation mission and set out in the staff report. The Government proposes to increase spending by more than double that in the original 2008 budget, and about 50 percentage points higher than previously expected for the MYBU. The bulk of the increase is reportedly for a new Economic Stabilization Fund (ESF) to stabilize the price of rice and other foods, fuel, and construction materials. To finance the higher appropriations, the MYBU implies an additional withdrawal from the Petroleum Fund of 61 percent of nonoil GDP above the estimated sustainable level, which requires special approval from Parliament.

\begin{tabular}{|c|c|c|c|c|c|}
\hline \multicolumn{6}{|c|}{$\begin{array}{l}\text { Central Government Budget } \\
\text { (In percent of non-oil GDP) }\end{array}$} \\
\hline & \multicolumn{2}{|c|}{$2007 \mathrm{H} 2$} & \multicolumn{3}{|c|}{2008} \\
\hline & \multirow[b]{2}{*}{ Budget } & \multirow[b]{2}{*}{ Act. } & \multirow[b]{2}{*}{ Budget } & \multicolumn{2}{|c|}{ MYBU Est. } \\
\hline & & & & SM/08/165 1/ & MYBU 2 \\
\hline Revenue & 291 & 350 & 291 & 423 & 418 \\
\hline of which oil and gas & 281 & 340 & 287 & 417 & 410 \\
\hline Expenditure (commitments) & 55 & 52 & 72 & 105 & 154 \\
\hline Current & 52 & 44 & 53 & 76 & 121 \\
\hline Capital & 3 & 8 & 19 & 29 & 33 \\
\hline Expenditure (cash) 3/ & $\ldots$ & 31 & $\ldots$ & $\ldots$ & $\ldots$ \\
\hline Current & $\ldots$ & 30 & $\ldots$ & $\ldots$ & $\ldots$ \\
\hline Capital & $\ldots$ & 1 & $\ldots$ & $\ldots$ & $\ldots$ \\
\hline \multicolumn{6}{|l|}{ Memorandum items: } \\
\hline Cash opening balance 4/ & 115 & 115 & 38 & 38 & 38 \\
\hline Carry-over opening balance $3 / 4$ / & 59 & 59 & 20 & 20 & 20 \\
\hline Carry-over spending $5 /$ & 59 & 22 & 20 & 20 & 20 \\
\hline Total cash spending $5 /$ & 114 & 53 & 92 & 125 & 174 \\
\hline 'Sustainable' spending & 77 & $\ldots$ & 66 & 90 & 92 \\
\hline \multicolumn{6}{|c|}{$\begin{array}{l}\text { Sources: Timor-Leste authorities; and Fund staff estimates } \\
1 \text { / Preliminary, as of mid-May. Cost of rice subsidies ( } 5.8 \text { percent of non-oil GDP) } \\
\text { is included in current expenditure on a net basis. } \\
2 \text { / Approved by Council of Ministers June } 18 \text {. Includes } 51 \text { percent of non-oil GDP } \\
\text { for an economic stabilization fund. } \\
3 \text { / Cash spending of current budget. } \\
4 \text { / Figures for } 2007 \mathrm{H} 2 \text { are higher because of comparing to half-year GDP. } \\
\text { 5/ Figures in budget columns assume full cash execution, also of carry-over. }\end{array}$} \\
\hline
\end{tabular}

3. The proposed MYBU reinforces concerns raised in the staff appraisal, including the need for well planned and managed spending to guard against waste. While the proposal reflects the government's desire to respond to rising commodity prices, the scope is considerably larger than earlier plans for the rice subsidy. Given still undefined operational details, weak administrative capacity, and the timing, it is not expected that much of the ESF appropriation could be spent in the remaining half of the fiscal year. In addition, initial public reaction suggests the MYBU proposal will encounter significant opposition in Parliament. 


\section{INTERNATIONAL MONETARY FUND}

EXTERNAL

Public Information Notice

RELATIONS

DEPARTMENT

Public Information Notice (PIN) No. 08/78

FOR IMMEDIATE RELEASE

International Monetary Fund

June 30, 2008

$70019^{\text {th }}$ Street, NW

Washington, D. C. 20431 USA

\section{IMF Executive Board Concludes Article IV Consultation with Democratic Republic of Timor-Leste}

On June 25, 2008, the Executive Board of the International Monetary Fund (IMF) concluded the Article IV consultation with Democratic Republic of Timor-Leste. ${ }^{1}$

\section{Background}

Growth rebounded in 2007, although the civil unrest continues to undermine the economy. Following negative growth in 2006 , the peak year for the civil unrest, non-oil growth is estimated to have reached almost 8 percent in 2007 and should remain high in 2008. Growth is driven mainly by the public sector, as government expenditure surges and donor spending remains high. Agricultural production contracted in 2007 due to drought and locust infestations. Output of coffee, the main non-oil export commodity, fell by an estimated 20 percent. Private sector activity remains subdued by the security situation.

Inflation has risen sharply, but remains low relative to regional comparators. Consumer prices increased by 8.9 percent in 2007 and are likely to stay high in 2008, driven by rising global food prices and reflecting food's 60 percent weight in the CPI basket. Fuel prices have also risen in line with international prices. While government subsidies for rice have partially shielded consumers, the threat of rice shortages looms. Excluding food prices, inflation was relatively low, although signs of increased demand-side price pressures are emerging in tight markets, e.g., in construction materials.

\footnotetext{
${ }^{1}$ Under Article IV of the IMF's Articles of Agreement, the IMF holds bilateral discussions with members, usually every year. A staff team visits the country, collects economic and financial information, and discusses with officials the country's economic developments and policies. On return to headquarters, the staff prepares a report, which forms the basis for discussion by the Executive Board. At the conclusion of the discussion, the Managing Director, as Chairman of the Board, summarizes the views of Executive Directors, and this summary is transmitted to the country's authorities.
} 
The weakening U.S. dollar and low inflation contributed to a moderate depreciation of the real effective exchange rate over the past year. On a nominal trade-weighted basis, the exchange rate is unchanged relative to 2004. Revenue from off-shore oil/gas continues to surge, reflecting high international prices. Petroleum revenue reached 340 percent of non-oil GDP in 2007, with petroleum fund assets increasing to US $\$ 2.6$ billion at end-March 2008 (about 6 times non-oil GDP).

The large revenue inflows more than offset the steep increase in government expenditure, as external and fiscal surpluses further widened. Central government spending almost doubled in FY2006/ $/ 07^{2}$, with a further increase in spending during the second half of 2007, as reflected in expanding non-oil deficits. Government expenditure drove a surge in merchandise imports, which also almost doubled to an estimated 51 percent of non-oil GDP.

The increase in government expenditure has more than offset a gradual decline in donor spending. On a "combined sources" basis, which includes donor spending for projects identified in the national development plan, total public sector expenditure in FY2008 is expected to reach 101 percent of non-oil GDP. Although the recent civil unrest-related humanitarian needs have led to new commitments, international assistance is expected to decline further over the coming years.

Notwithstanding the sharp increase, government spending to date remains far below budgeted levels, especially for investment spending. Budget execution remains constrained by weak planning and procurement capacity, as financial management reforms have not yet had a significant impact. In addition, a large stock of unspent commitments continues to be carried forward, despite efforts to tighten procedures.

The planned 2008 mid-year budget update (MYBU) includes a significant increase in current spending appropriations. Additional funds are being allocated for public works programs, transfers to refugees, veterans and the elderly, and higher public sector salaries. The MYBU also includes a large appropriation for rice purchases (5.8 percent of GDP) to be used for subsidized resale to local retailers, distribution to civil servants, and humanitarian assistance. The 2008 budget update appropriations are expected to exceed the estimated "sustainable" spending level defined under the Petroleum Fund arrangement, but actual cash expenditure is likely to be significantly lower.

Access to financial services remains limited and credit growth has stalled. Notwithstanding the rapid expansion of credit to the private sector following independence (from a small base), still less than 2 percent of the population use banking facilities. A poor credit culture and weak enforcement of creditors' rights, compounded by the recent civil unrest, has led to an increase in nonperforming loans and provisioning to, respectively, 28 percent and 53 percent of bank

\footnotetext{
${ }^{2}$ Fiscal years end in June up to FY2006/07. The government budget moved to a calendar year basis in 2008; the second half of 2007 was covered by a transition budget.
} 
lending at end-March 2008. While bank deposits have increased sharply, there has been little credit growth since 2006, with banks placing excess funds abroad.

The civil unrest and mid-2007 general elections have delayed progress on structural reforms needed to support non-oil private sector activity. A draft of critical economic legislation is still pending. The court system is overwhelmed and there is no effective system to enforce contractual rights or settle disputes. Business licensing regulations appear to have become more complicated, rather than simplified as needed.

The medium-term outlook is for moderate non-oil growth. The outlook is shaped by, on the one hand, expected continued favorable oil/gas revenue prospects, and on the other, constraints on the government's capacity to spend. Given current trends, the "sustainable" spending level would be reached within a couple of years as budget execution gradually improves. Under that assumption, and based on continued slow reform of the business environment, the non-oil economy should grow by about 5 percent annually over the medium term. A more forceful shift in the spending mix toward well-planned investment spending and successful business environment reform would be associated with annual growth rising to above 8 percent and less inflationary pressure.

\section{Executive Board Assessment}

Executive Directors praised the authorities for Timor-Leste's solid recent macroeconomic performance. Despite civil unrest, macroeconomic stability has been maintained, aided by a sound fiscal and monetary framework. Looking forward, the key challenge remains to use the growing oil and gas revenue to develop a sustainable non-oil economy, while alleviating social problems and maintaining macroeconomic stability.

Directors believed that the strategy set out in the current National Development Plan remains valid. This includes the long-term oil and gas revenue savings policy, well-targeted development spending, a monetary and exchange rate regime that preserves macroeconomic stability, and a supportive environment for private investment and activity.

To ensure sustainable growth and poverty reduction, Directors stressed the need to encourage the development of the private sector. The comfortable level of resources should permit a stepping up of public investment in support of this, particularly in infrastructure and human capital development, as well as expenditures to address immediate security and humanitarian needs. Directors welcomed the tax reform, which should promote business formation, and called for further reforms to simplify business regulations, clarify land tenure rights, and improve the judicial system.

Directors observed that the increase in government expenditure planned for the midyear 2008 budget will call for careful planning and monitoring to ensure that such expenditure is productive while avoiding inflationary pressures. Adoption of cash-based budgeting would also be helpful. Directors noted the importance of enhancing Timor-Leste's administrative and absorptive 
capacities so that budget operations are accomplished efficiently and in a timely manner, and in full accordance with the authorities' program goals. Continued technical assistance will be needed in this regard. Looking further ahead, Directors encouraged the authorities to develop a medium-term fiscal framework that is in line with macroeconomic stability and the country's absorptive capacity.

Directors viewed the Petroleum Fund as a cornerstone for sound management of the country's resources, ensuring fiscal sustainability and macroeconomic stability. The Fund smoothes budget spending, provides for investment abroad of resources not required for budget execution, and mandates transparency in its operations. Looking forward, Directors encouraged the authorities to preserve these principles. They welcomed the acceptance of Timor-Leste as a candidate country in the Extractive Industries Transparency Initiative (EITI).

Directors agreed that the use of the U.S. dollar as the currency of Timor-Leste has served the economy well by providing a credible nominal anchor for price stability. They noted the staff assessment that the current level of the exchange rate appears broadly consistent with its equilibrium level. They observed that stronger institutional capacity will be needed before considering a move to introduce a national currency.

Directors welcomed the initiatives to strengthen the financial sector, including the progress made on a credit registry and the strengthening of banking supervision. Additional efforts are needed on pending financial sector legislation and the creation of an alternative dispute resolution mechanism. Any public sector participation in the financial system should be on commercial terms and supervised under domestic banking laws. Directors cautioned that proposals to begin external borrowing should be weighed carefully and analyzed transparently to ensure that such borrowing is adequately concessional, will deliver a clear net positive rate of return, and is consistent with macroeconomic stability.

Directors commended the authorities for the progress made on the compilation of financial and balance of payments statistics. They encouraged them to better monitor real sector activity through the compilation of national accounts.

Public Information Notices (PINs) form part of the IMF's efforts to promote transparency of the IMF's views and analysis of economic developments and policies. With the consent of the country (or countries) concerned, PINs are issued after Executive Board discussions of Article IV consultations with member countries, of its surveillance of developments at the regional level, of post-program monitoring, and of ex post assessments of member countries with longer-term program engagements. PINs are also issued after Executive Board discussions of general policy matters, unless otherwise decided by the Executive Board in a particular case. The staff report (use the free Adobe Acrobat Reader to view this pdf file) for the 2008 Article IV Consultation with the Democratic Republic of TimorLesteis also available. 
Democratic Republic of Timor-Leste: Selected Economic Indicators, 2003-08

\begin{tabular}{|c|c|c|c|c|c|c|}
\hline & 2003 & 2004 & 2005 & 2006 & $\frac{2007}{\text { Proj. }}$ & $\frac{2008}{\text { Proj. }}$ \\
\hline \multicolumn{7}{|l|}{ Output and prices } \\
\hline GNI at current prices (US\$ million) & 318 & 459 & 696 & 974 & 1,725 & 2,464 \\
\hline Non-oil GDP at current prices (ÚS\$ million) & 298 & 309 & 332 & 327 & 396 & 473 \\
\hline Real non-oil GDP growth (percentage change) & 0.1 & 4.2 & 6.2 & -5.8 & 7.8 & 6.8 \\
\hline Including Untied Nations $1 /$ & -6.2 & 0.4 & 2.3 & -3.4 & 16.2 & 4.7 \\
\hline Inflation (percentage change, end-period) 2/ & 4.2 & 2.5 & 1.0 & 6.7 & 7.6 & 9.0 \\
\hline \multirow[t]{2}{*}{ Inflation (percentage change, period average) $2 /$} & 7.2 & 3.2 & 1.8 & 4.1 & 8.9 & 9.0 \\
\hline & \multicolumn{6}{|c|}{ (In percent of non-oil GDP) } \\
\hline \multicolumn{7}{|l|}{ Investment-saving balance } \\
\hline Gross investment 3/ & 29 & 21 & 21 & 21 & 28 & 31 \\
\hline Gross national savings & 22 & 29 & 103 & 183 & 323 & 387 \\
\hline External savings & 8 & -9 & -82 & -162 & -295 & -357 \\
\hline \multicolumn{7}{|l|}{ Central government budget $4 /$} \\
\hline Revenues & 35 & 105 & 157 & 289 & 350 & 424 \\
\hline Domestic revenues & 10 & 12 & 10 & 11 & 10 & 7 \\
\hline Oil/gas revenues & 14 & 83 & 146 & 275 & 340 & 417 \\
\hline Grants & 11 & 11 & 0 & 3 & 0 & 0 \\
\hline Expenditure (cash basks) & 21 & 22 & 26 & 48 & 53 & 71 \\
\hline Recurrent expenditure & 20 & 19 & 21 & 39 & 41 & 57 \\
\hline Capital expenditure & 1 & 3 & 5 & 9 & 12 & 14 \\
\hline Overall balance & 14 & 83 & 131 & 242 & 297 & 352 \\
\hline Non-oil fiscal balance & 0 & 0 & -16 & -33 & -43 & -65 \\
\hline Public debt & 0 & 0 & 0 & 0 & 0 & 0 \\
\hline Cumulative oil/gas savings & 4 & 5 & 112 & 310 & 527 & 810 \\
\hline \multicolumn{7}{|l|}{ Combined sources fiscal operations $4 / 5$ / } \\
\hline Domestic revenue and budget grants & 23 & 25 & 13 & 16 & 12 & 8 \\
\hline Expenditure & 68 & 67 & 64 & 83 & 88 & 101 \\
\hline Recurrent expenditure & 52 & 50 & 47 & 64 & 66 & 78 \\
\hline Capital expenditure & 16 & 16 & 17 & 20 & 22 & 23 \\
\hline Overall balance & -45 & -42 & -51 & -67 & -77 & -93 \\
\hline \multicolumn{7}{|l|}{ Money and credit } \\
\hline Broad money (end-period) 6/ & 21 & 21 & 23 & 31 & 36 & 40 \\
\hline \multirow{2}{*}{ Net domestic assets (end-period) } & -15 & -38 & -24 & -3 & -44 & -24 \\
\hline & \multicolumn{6}{|c|}{ (In millions of U.S. dollars) } \\
\hline \multicolumn{7}{|l|}{ External sector } \\
\hline Current account excl. international assistance & -479 & -321 & 34 & 295 & 771 & 1,333 \\
\hline Current account incl. international assistance & -23 & 26 & 273 & 531 & 1,168 & 1,689 \\
\hline Merchandise exports $7 /$ & 8 & 8 & 9 & 9 & 8 & 11 \\
\hline Merchandise imports & -130 & -129 & -125 & -123 & -200 & -309 \\
\hline \multirow[t]{2}{*}{ Overall balance } & 18 & 121 & -29 & -70 & 147 & 0 \\
\hline & \multicolumn{6}{|c|}{ (In percent of non-oil GDP) } \\
\hline Current account excl. international assistance & -161 & -104 & 10 & 90 & 195 & 282 \\
\hline Current account incl. international assistance & -8 & 9 & 82 & 162 & 295 & 357 \\
\hline Overall balance & 6 & 39 & -9 & -21 & 37 & 0 \\
\hline
\end{tabular}

Sources: Data provided by the Timor-Leste authorities; and Fund staff estimates.

$1 /$ Includes locally paid compensation of UN peacekeeping mission staff.

2/ Whole of the country CPI from 2003.

3/ Excludes oil/gas sector investment.

4/ Fiscal years (July-June) up to FY2006/07 (in column for 2006); Fiscal year corresponds to calendar years from 2008.

5/ Includes autonomous agencies and quasi-fiscal expenditure programs undertaken by bilaterals and multilaterals outside the central government budget. The revenue decline in 2005 reflects the creation of the petroleum fund, to which oil revenue now accrues. Income from the fund and donor grants finance the fiscal deficit.

6/ Excludes currency holdings by the public, for which no data are available.

7/ Excludes oil/gas revenue, which is recorded as income, and re-exports, which primarily relate to repatriation of UN peacekeeping equipment. 


\section{Statement by Arrigo Sadun, Executive Director for the \\ Democratic Republic of Timor-Leste, and \\ José Cardoso, Advisor to Executive Director \\ June 20, 2008}

On behalf of the Timorese authorities, we wish to express our sincere gratitude and appreciation to the staff for the thorough, constructive, and insightful approach to this Article IV Consultation. The Timorese authorities welcome the IMF consultations, as well as the very interesting technical discussions and presentations to Timorese officials and staff, since they provide a unique opportunity to discuss policy options and IMF recommendations.

\section{Introduction}

Timor-Leste has been gradually reinforcing its democratic institutions and maturity, but this construction has not been a smooth process. The emergence of the crisis in 2006, triggered by rivalry within the Timorese security forces that rebelled, and the insecurity resulting from it, illustrate the extreme fragility of this post-conflict country. Notwithstanding the severe adversities, the country has already clearly demonstrated its democratic maturity when it comes to elections. Timor-Leste held a national presidential election in April and May 2007, and legislative elections in June 2007. These were the first national post-independence elections organized by the Timorese authorities and, as such, were an important step in the consolidation of democracy in the country.

The population of Timor-Leste is about one million inhabitants. More than half is illiterate and most of the labor force (over 4/5) gets its subsistence from agriculture and fishery. After independence, the population has grown at a rate of about 3.5 percent a year. About 70 percent of the population is under 30-years-old and life expectancy is about 56 years old. Unemployment rates are high, especially in the capital (home to about a quarter of the labor force) and among youth aged 15 to 29. In this last group (youth workforce in the capital), unemployment stands at about 40 percent. The full reintegration of some one hundred thousand Internally Displaced Persons (IDPs) is far from achieved. About $30 \%$ of them continue to reside in 58 camps, mainly in the capital. Timor-Leste is ranked 150 out of 177 countries in the 2007/2008 United Nations Development Programme (UNDP) Human Development Index (HDI). Estimates suggest that as much as $42 \%$ of the population is now below the national poverty line of $\$ 0.55$ per day, which reveals a deterioration of this indicator during recent years. Compared with the countries of the ASEAN region, TimorLeste is the poorest country, with non-oil GDP per capita of \$378 in 2007. 


\section{Macroeconomic overview}

Following the civil unrest of 2006 - responsible for a contraction of real non-oil GDP (which excludes offshore oil and natural gas, and the UN contribution to government operations) of about 5.8 percent - real non-oil GDP is estimated to have rebounded to 7.8 percent in 2007, largely driven by government and donor spending. Economic recovery could have been higher if not for the unstable security conditions that subdued private activity, and the drought and locust infestations that generally hit agricultural production. In the case of coffee, the main export crop, the decline in production was about 20 percent.

The government's prudent and responsible macroeconomic framework has successfully contained inflation in Timor-Leste, but recent shocks pose some risks to price stability and food security to the most vulnerable population.

Important policy measures adopted by the Timorese authorities have proven its effectiveness in containing inflation, namely (i) the USD as the currency of legal tender - whose simplicity is well-suited for the country's constraints and provides an effective nominal anchor for price stability (notwithstanding the negative effects of its recent depreciation in a country very dependent upon imports) - along with (ii) the strategy to invest abroad the wealth from oil-and-gas, and (iii) the responsible fiscal policy tracked by sustainable spending defined by the Petroleum Fund Law (explained in section 3). Within this adequate macroeconomic framework, inflation has stood at levels well below that of comparator countries.

However, the higher international food prices, especially rice, were an exogenous shock that, along with poor harvests and some difficulties to secure normal imported rice levels, instigated a hike in inflation in the first quarter of 2007. However, by the end of the year, the price level had already fallen significantly and inflation averaged 8.9 percent over the year. It should be noted that food represents a high portion of the CPI (about 58 percent) and that about half of the food items are imported. Excluding food, inflation actually recorded a slight reduction in 2007 to under 3.5 percent on average. Whether including or excluding food in the CPI, inflation in Timor-Leste remains relatively low when compared regionally with similar countries or with its trading partners.

The authorities recognize that external and supply-side shocks may pose some risks to price stability. As inflation, essentially on food items, particularly hurts the most vulnerable population, and since the most pressing item has been the price of rice, the authorities have decided to import rice for resale to local retailers at subsidized prices. This measure, representing an additional cost to the budget, has successfully mitigated the pass-through of international rice prices, and its benefits are being essentially felt by the poor, given the relatively high portion of their income that is spent on rice.

The external current account and the fiscal position have continued to accrue rising surpluses, notwithstanding sharply increased government spending, since the offshore oil-and-gas sector has not been affected by the civil unrest, and reflecting rising revenues due to a peak in production and high international prices. Petroleum revenue reached 340 percent of non-oil 
GDP in 2007, with petroleum fund assets increasing to \$2.6 billion at end-March 2008 (about 6 times non-oil GDP). The Greater Sunrise oil/gas field could commence production by 2014 , although serious questions remain on the project's financial viability.

The sharp increase recorded during 2007 in government spending must be understood by the fact that government spending has been covering the gradual decline in donors spending. Therefore, the rise in total expenditure effectively spent has been much lower than the rise in government spending. However, the authorities are vigilant to any demand pressures that might arise given the limited absorption capacity of the domestic economy, especially if the increasing management capacity starts to produce results on higher rates of budget execution. The Timorese authorities note that, in the staff's financial programming for 2008, projected government cash spending is the double of that in FY2006/07 and 60 percent higher than the annual rate in the second half of 2007. This is an optimistic sign that the measures in progress by the Timorese authorities are expected to be effective in strengthening management capacity.

Additionally, despite the rise in government spending, it remained far below appropriations and the sum of sustainable resources drawn from the Petroleum Fund, in strict respect of the Petroleum Fund Law. Less than 60 percent of the transitional 2007 budget (second half of 2007) was spent on a cash basis, with an execution rate of just 12 percent for capital expenditure. The carry-over of financial resources, due to significant execution difficulties that delay spending to the next financial year, does not represent a violation of the Petroleum Fund Law. Resources drawn from the Petroleum Fund have respected the annual estimated sustainable limits established by the Law. Some procedures have already been introduced to limit the carry-over of obligations between fiscal years, but the authorities recognize that the execution constraints will continue to be felt for the near future, although less pronouncedly over time.

As to the financial system, the rise in nonperforming loans and provisioning reflect essentially the deterioration of the recent past security conditions. At present, the fact that several commercial banks — which are branches of foreign banks - already expressed interest in opening new branches within the country outside the capital suggests no evidence of a systemic risk.

\section{Oil and gas resources}

With the purpose of managing the revenues from oil-and-gas production in a way to assure not only inter-generational equity but also fiscal sustainability, the Timorese authorities established in 2005 the Timor-Leste Petroleum Fund, modeled after the Norwegian petroleum fund experience on such type of sovereign wealth fund, and with the valued support from the IMF and other external partners. The Petroleum Fund is integrated into the central government budget. Transfers from the Petroleum Fund to the budget are subject to a spending ceiling set on the basis of the fiscal sustainability policy. The annual sustainable spending is equal to the sum of the estimated permanent (interest) income from the oil-and-gas wealth and domestic non-oil revenue. The Petroleum Fund Law allows drawings to exceed the sustainable level, if necessary and justifiable as being in the long-term interest of the country, under approval by the parliament, through a highly responsible and 
transparent process, but this option has never been used. The Petroleum Fund assets are invested abroad to limit risk and minimize real exchange rate appreciation pressures.

The Minister of Planning and Finance is responsible for the overall management and investment strategy of the Petroleum Fund, and the operational management is the responsibility of the Banking and Payments Authority (BPA) - the incumbent central bank. The BPA submits quarterly reports on the performance of the Petroleum Fund to the Minister of Planning and Finance. In turn, the Ministry publishes an annual report containing a more complete description of the Petroleum Fund's activities and the financial statements certified by an internationally recognized audit firm. The Petroleum Fund is generally considered at the top of international rankings for transparency and accountability. Additionally, an Investment Advisory Board provides strategic investment advice concerning the investments of the Petroleum Fund to the Minister of Planning and Finance, and an independent Consultative Council advises Parliament on Petroleum Fund issues.

Regarding the investment strategy, all assets have been invested in short and medium-term U.S. government bonds and managed passively to track the Merrill Lynch US government bond index. The government recognizes that it is now time to develop a long-term investment strategy. In this regard, the Timorese authorities announced this month that a step was already taken forward in the operational management of the Petroleum Fund by signing a Global Custody Agreement, following an international tender procurement process, with an internationally recognized financial services firm, to act as the global custodian for the Petroleum Fund's assets.

Besides the effective custody of the investments, the Agreement also includes the provisioning of related services. This firm will receive and arrange the settlement of trading instructions from external managers, and will monitor their performance. This step will support the future appointment of specialized external managers to manage portions of the Petroleum Fund, a necessary move to implement the government's intention to broaden the investment mandate of the Petroleum Fund, in order to achieve higher long-term returns. Additionally, this firm will also provide the BPA with investment performance and compliance services, as well as the Petroleum Fund's financial accounting and reporting. This is the first-step in the implementation of the BPA's strategy to form a team of finance professionals to manage the assets of the Petroleum Fund. The Timorese authorities appreciate the assistance of the World Bank and BIS for the initial phase of this challenging process.

After some meetings of Timor-Leste's Multi-Stakeholder Working Group for the Extractive Industries Transparency Initiative (EITI) initiated last year — which brought together representatives from relevant government agencies, civil society, and the petroleum industry - Timor Leste was accepted in February as an EITI Candidate Country. The Secretary of State of Natural Resources is the government official responsible for undertaking the EITI validation. In this area — as in the one related to the Petroleum Fund the Timorese authorities are deeply committed to fully complying with the international bestpractices. 


\section{Poverty reduction and structural reforms}

Despite the broadly recognized meritorious efforts to manage oil-and-gas resources, progress on economic and social development has been more elusive, and the population has yet to see any real change in their daily lives. A general perception exists that the wealth from oil-and-gas resources has not been directed to social support, which has put significant pressure on solving immediate social problems. However, the problem has resided on the country's poor budget execution, namely on investment spending, due to a weak administrative capacity and, to some extent, domestic disturbances. The Timorese authorities recognize that the broad challenge is how to implement economic and social development measures to alleviate immediate social needs and security problems, while developing a strong non-oil economy and maintaining low inflation. In this regard, we should distinguish between short-term priorities and long-term priorities.

Short-term priorities pursue the immediate goal of food security and social cohesion. An important measure to assure food security was the subsidization of the price of rice, which successfully shielded the most vulnerable population from the threat of famine due to supply shortages looms, weather disturbances, and plagues that have recently disrupted agricultural production. Additionally, after the 2006 civil unrest, the authorities have been vigilant to factors that might trigger threats to the security conditions. A pacification policy has been followed to ensure public safety through the reintegration of petitioners from the 2006 rebellion into military and civilian life, and IDPs into an integrated life, with particular attention to housing, under the National Recovery Strategy endorsed by the Timorese authorities in December 2007 with the involvement of the United Nations, development partners, and civil society. Finally, the severe difficulties that elderly and disabled people are facing are also being addressed. All these measures - further strengthened in the 2008 midyear budget update, recently approved by the Council of Ministers and to be sent to parliament shortly - respond to the rationale that it is not possible to foster economic development without solving first the most basic needs of food security and social cohesion.

Long-term priorities aim the development of a sustainable non-oil economy within a stable macroeconomic environment. For more than two decades in the recent past, the public administration employed civil servants with very low levels of productivity, while productive sectors of the economy were left underdeveloped. As a result of this approach - which is still a very entrenched mindset - the private sector continues to be very insipient, consisting of micro and small-businesses that have been unable to create employment and are very much dependent upon Government contracts. The authorities are determined to reform the business environment - which has been constraining some meritorious private initiatives and, according to the recent 2008 Doing Business report, is still ranked very low, although improving - to enhance competitiveness and to promote a self-creating employment private sector. In this regard, the authorities agree on the need to strengthen public investment in three areas: (i) infrastructure, namely road building, housing, water supply, and electricity generation, among other important projects, using labor-intensive strategies whenever possible and adequate, to promote employment among a vast low-skilled population; (ii) human capital, through the strengthening of the educational system and professional qualification (including the introduction of a policy of free basic education and nine years of compulsory attendance in school); and (iii) institutional and regulatory framework. 
In this last area, an important incentive to foster the private sector is the tax reform recently approved by parliament. The new non-petroleum tax system significantly reduced tax rates, lowered compliance costs, and streamlined regulations. The expected decline in non-oil tax revenue, from about 10 percent to 5 percent of non-oil GDP, is a budgetary cost that the authorities assume in this effort to create the necessary conditions to boost a formal private sector in Timor-Leste, taking advantage of the sustainable fiscal space derived from oil-and-gas revenues.

Now that the tax reform has been completed, the authorities plan to address other important bottlenecks to the economic activity, namely: (i) to promote measures to expand access to financial services, especially in the districts, by encouraging the expansion of existing commercial banks' branches of established foreign banks, and by creating a National Development Bank, run on a commercial basis and supervised under domestic financial law (although the plans for the National Development Bank are still under analysis); (ii) to implement a land reform, expected to be completed by the end of the year, in order to create a framework for land ownership, titling, and registration; and (iii) to advance with the judicial reform, including judicial decisions enforcement. For these purposes, again, substantial physical and human investment is necessary, along with technical support to create the necessary expertise.

If a strategy of external debt borrowing is adopted to cope with the financial requirements for these long-term priorities, one of the areas in which expertise would have to start from scratch would be debt management. Being one of the youngest countries in the world, Timor-Leste has no external public debt. Although eventually justifiable from a financial point of view, the recourse to external financing will have to be carefully studied through a cost/benefit analysis. For the very immediate future, external financing could prove to be less favorable when compared with the possibility of using resources from the Petroleum Fund.

Given the lower donor support and the above explained severe needs that the country is facing, the 2008 mid-year budget update, to be sent to parliament shortly, presents those needs and justifies, as being in the long-term interest of the country, spending above the estimated sustainability limit. Notwithstanding the still pressing execution difficulties that probably will contain spending below this limit, the government - conscientious of a potential inflationary risk from higher government spending in a country with a limited absorption capacity - intends to contain any inflationary pressures, which may be felt essentially on construction materials. In this regard - and included in a broad measure to keep a tight vigilance on price developments, under the exchange rate regime of official dollarization - the government already approved this week the establishment of a Fund for Economic Stability, to contain the rise in prices of food, fuels, and construction materials. Therefore, the medium-term goal of this Fund is to reconstruct the capacity of the economy and to develop programs to help the population deal with the effects of the crisis, in support of the achievement of the above explained short and long-term priorities within a stable macroeconomic framework.

To conclude, we emphasize that all the decisions already taken and to be sent to parliament for approval respect the Law and all the transparency requirements that characterize the Timor-Leste Petroleum Fund. 


\section{Final remarks}

Timor-Leste is living a time of great opportunity. After the rebel attacks in February, the rebels have surrendered, disturbances have significantly diminished, and the country has returned to a state of normalcy. However, the fragility of this post-conflict country remains latent pending the near-term consolidation of the social cohesion and the eradication of food insecurity, and the long-term development of a sustainable formal non-oil economy. Under the current circumstances, the involvement of the international community is essential to sustain the current juncture.

On the economic sphere, in which the IMF has a particular role and responsibility, the task is huge and requires a permanent in situ counseling. The Timorese authorities reiterate their high appreciation for the IMF support and count on the current level of involvement to not be abruptly interrupted in the immediate future. To conclude, the Timorese authorities express their deepest appreciation for the competence and personal engagement of the IMF resident representative. 